\title{
A GEOSPATIAL ASSESSMENT OF SOCIAL VULNERABILITY TO SEA-LEVEL RISE IN COASTAL SAN LUIS OBISPO COUNTY
}

\author{
A Thesis \\ presented to \\ the Faculty of California Polytechnic State University, \\ San Luis Obispo
}

In Partial Fulfillment

of the Requirements for the Degree

Master of City \& Regional Planning

by

Jesse Ann Carpentier

June 2017 
(C) 2017

Jesse Ann Carpentier

ALL RIGHTS RESERVED 


\section{COMMITTEE MEMBERSHIP}

TITLE: A Geospatial Assessment of Social Vulnerability to Sea-Level Rise in Coastal San Luis Obispo County

AUTHOR: Jesse Ann Carpentier

DATE SUBMITTED: June 2017

COMMITTEE CHAIR: Michael Boswell, Ph.D.

Professor of City \& Regional Planning

COMMITTEE MEMBER: Adrienne Greve, Ph.D.

Associate Professor of City \& Regional Planning

COMMITTEE MEMBER: Chris Read

EnergyWise Program Coordinator at the County of San Luis Obispo 


\begin{abstract}
A Geospatial Assessment of Social Vulnerability to Sea-Level Rise in Coastal San Luis Obispo County

Jesse Ann Carpentier
\end{abstract}

This project is an assessment of social vulnerability to sea-level rise in the unincorporated coastal area of the County of San Luis Obispo (County) using geospatial and statistical analysis. The intention of this assessment is to inform local climate adaptation efforts now required by state legislation. A social vulnerability index was generated at the Census block group level using 37 variables positively correlated with social vulnerability. The results of a principle components analysis show that the social vulnerability index for San Luis Obispo County includes (1) language and ethnicity (2) household status, (3) age and social isolation, (4) dependence on social services, and (5) race and occupation. The social vulnerability index is a useful tool for spatializing social vulnerability. Geographic Information Systems software is used to map social vulnerability scores and building footprints attributed to each block group in the coastal planning area. To provide a preliminary assessment of exposure to sea-level rise hazards, social vulnerability and buildings are overlaid with existing spatial datasets for inundation, bluff erosion, dune erosion, and wetland migration induced by projected sea-level rise in the year 2100. Implications for existing plans include the incorporation of sea-level rise vulnerability into the general plan (safety, land use, and environmental justice elements in particular), local hazard mitigation plan, and local coastal programs. It is also noted that mapping social vulnerability at the block group level is not as precise as that of the block- or parcel-level. A higher resolution assessment of social vulnerability can be conducted in the future if data become available at either of those scales 


\section{ACKNOWLEDGMENTS}

First I would like to thank Bobby Jo Close, Jeffery Legato, and Russel White for providing technical assistance on this project. I would like to extend my gratitude to the individuals who ultimately made this accomplishment possible: Gramma Dotty and Grampa Jack for funding my education and supporting me since I was born; my sisters, mother, father, and stepmother for their generosity, wisdom, and humor; my dear friends Julia Isabella Cannata, Brian Clarke, Brandon Drucker, Katelin Eden, Julia Hall, and Julian Summers for their unceasing patience, compassion, and encouragement; Dr. Michael Boswell, Jeffrey Dunk, Dr. Adrienne Greve, Dr. Steven Hackett, Meg Henry, Morgan King, Dr. Cornelius Nuworsoo, and Rachel Ruppel for going above and beyond to support my personal and professional growth. 


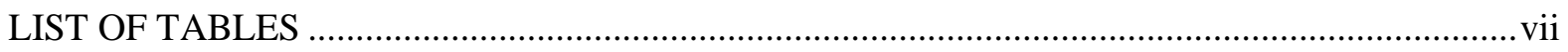

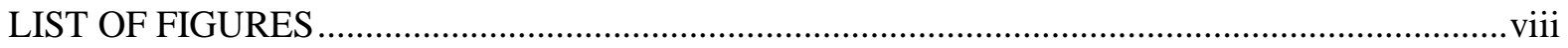

\section{CHAPTER}

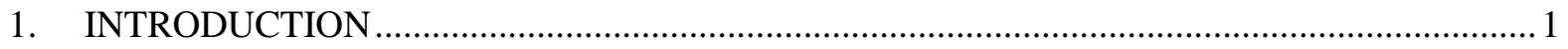

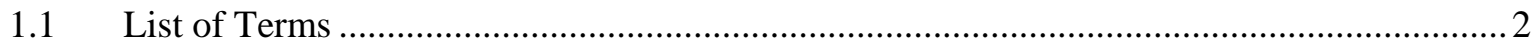

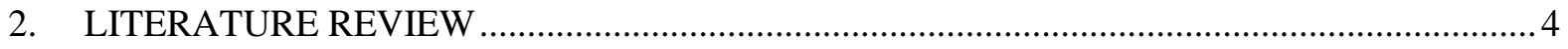

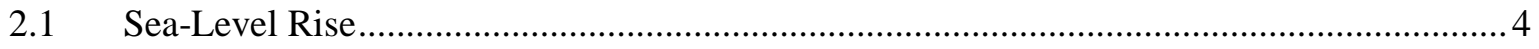

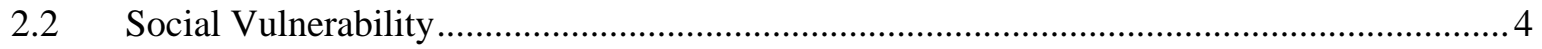

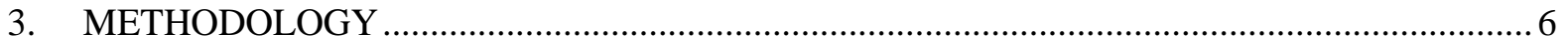

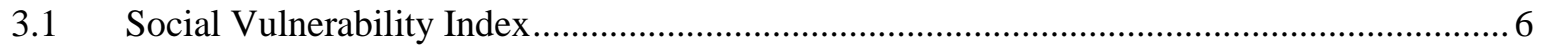

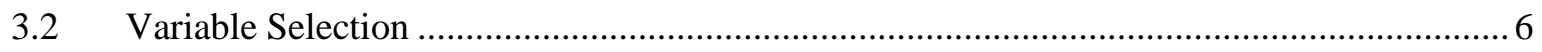

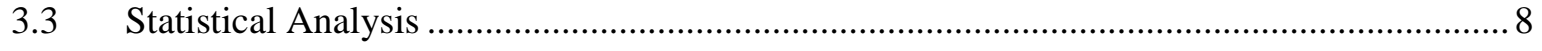

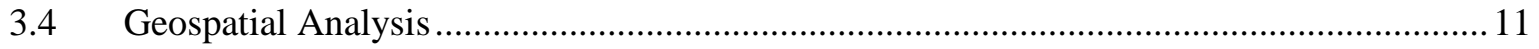

4. RESULTS

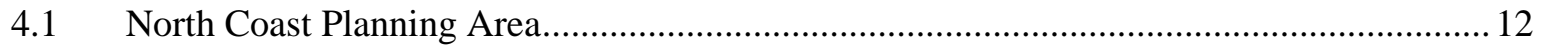

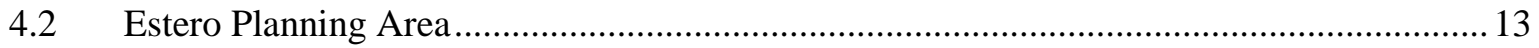

4.3 San Luis Bay Coastal Planning Area............................................................................... 13

$4.4 \quad$ South County Coastal Planning Area ................................................................................ 14

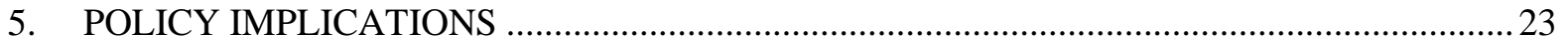

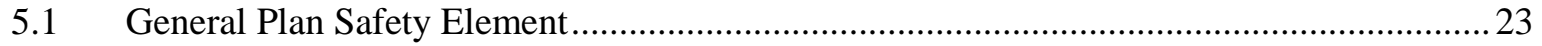

5.2 General Plan Land Use Element and Local Coastal Programs........................................... 24

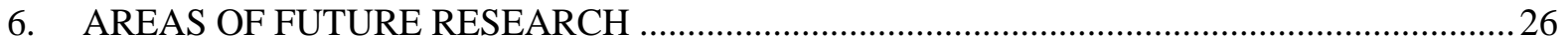

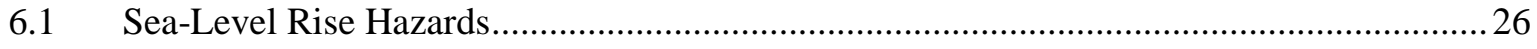

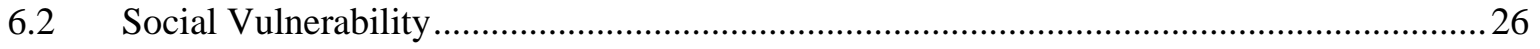

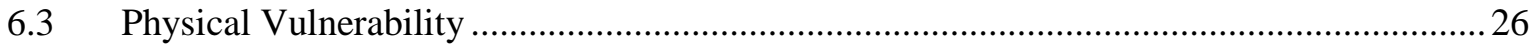

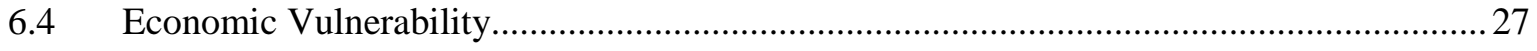

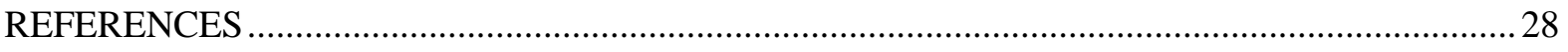

APPENDICES

APPENDIX A: SPSS Output from Principle Components Analysis ..................................................... 32

APPENDIX B: Component Scores and Total Social Vulnerability Score ........................................... 44

APPENDIX C: Referenced Geospatial Datasets............................................................................... 48 


\section{LIST OF TABLES}

Page

Table 2.1 Selected Variables for the Social Vulnerability Index .................................................. 7

Table 2.2 Components and Highest Factor Loadings................................................................... 10

Table 5.1 Recommendations for the Safety Element …................................................................. 23 


\section{LIST OF FIGURES}

Page

Figure 4.1 Social Vulnerability in San Luis Obispo County ...................................................... 15

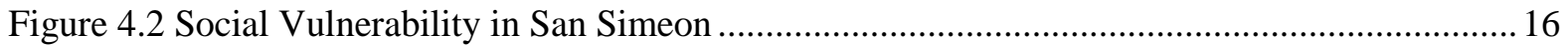

Figure 4.3 Social Vulnerability in Cambria.................................................................................... 17

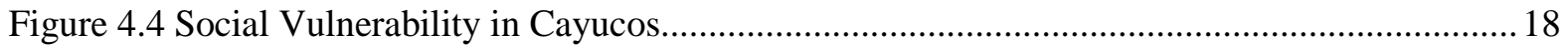

Figure 4.5 Social Vulnerability in Los Osos ….......................................................................... 19

Figure 4.6 Social Vulnerability in Avila Beach .............................................................................. 20

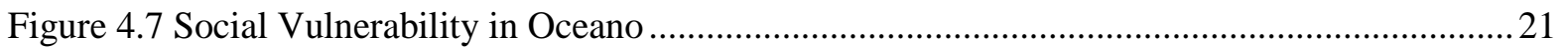

Figure 4.8 Social Vulnerability in Callendar-Garrett ............................................................................ 22 


\section{INTRODUCTION}

The concept of climate action planning, or the adoption of policies intended to address climate change, is not unfamiliar to many communities in California. The Global Warming Solutions Act of 2006 (AB 32) set statewide greenhouse gas reduction targets, followed by several other bills and executive orders intended to reduce the state's contribution to global climate change (California Air Resources Board 2014). Regardless of efforts to control the extent of climate change, it is already having substantial and measurable impacts in California and across the globe. In 2009, the California Natural Resources Agency prepared the "California Adaptation Strategy” as directed by Executive Order S-13-08. In 2014, the adaptation strategy was updated and renamed as "Safeguarding California: Reducing Climate Risk” which includes an assessment of and mitigation strategies for statewide climate change vulnerability. More recent legislation establishes a local responsibility to protect vulnerable populations and assets from those impacts.

SB 379 (2015) requires local agencies to incorporate climate adaptation and resiliency strategies into their local hazard mitigation plan or the safety element of their general plan, or the local hazard mitigation plans. The bill specifies that those strategies should be based on an assessment of vulnerability and local risks posed by climate change. SB 1000 (2016) requires that General Plans include an "environmental justice" element in addition to the other seven required elements. The environmental justice element must identify disadvantaged populations and include policies to address discrepancies in health and safety. Together, SB 379 and SB 1000 require local agencies to identify populations vulnerable to hazards induced by climate change, and develop corresponding mitigation strategies.

In 2015, the California Coastal Commission adopted "Sea Level Rise Policy Guidance: Interpretive Guidelines for Addressing Sea Level Rise in Local Coastal Programs and Coastal Development 
Permits” in 2015, which specifically calls for local agencies to consider sea-level rise in their local coastal programs. To inform local climate adaptation efforts now required by state legislation, this study assesses the vulnerability of populations in coastal San Luis Obispo County using geospatial and statistical analysis.

The methodology and findings of this study also contribute to the important body of literature on social vulnerability assessment as it relates to climate adaptation planning. Even outside of the legislative context, climate adaptation falls under the aegis of planning because it involves strategies related to land use, infrastructure, public health, natural resource management, and economic development. It is necessary to assess vulnerability to the different impacts of climate change to determine where, when, and to what extent adaptation planning is needed (CalEMA \& CNRA, 2012).

\subsection{List of Terms}

Adaptive capacity: Ability to cope with extreme events, make adaptive changes, prevent or reduce negative consequences, and utilize beneficial consequences (Moser \& Ekstrom, 2012).

Climate adaptation: Any adjustment in natural or human systems that minimizes negative consequences or utilizes beneficial consequences of climate change (EPA, 2016).

Community: Human population of individuals in a common location or with a common characteristic (Merriam-Webster, 2016).

Disaster: A sudden event that disrupts the functioning of a community or society and causes loss of life, property, economic resources, and/or natural resources (IFRC, n.d.).

Exposure: The inventory of elements in an area in which hazard events may occur (IPCC, 2001).

Hazard: An event that poses a potentially adverse impact (Cooley et al., 2012) 
Resilience: The capacity of a system to survive, adapt, and improve regardless of stresses and shocks (Moser \& Ekstrom, 2012).

Risk: The probability of harm if exposed to a hazard (FEMA, 2008).

Sensitivity: The extent to which a system is impacted by a stressor, change, or disturbance (Moser \& Ekstrom, 2012).

Vulnerability: The propensity of exposed elements such as human beings, their livelihoods, and assets to experience adverse impacts caused by hazard events (IPCC, 2001). 


\section{LITERATURE REVIEW}

The purpose of the following literature review is to provide a theoretical framework and identify the need for this study. Resources include government publications and academic reports on sea-level rise, social vulnerability, and their relevance to San Luis Obispo County.

\subsection{Sea-Level Rise}

Sea-level rise is an existing and continued impact of climate change, caused by melting ice caps and sheets, and land subsidence. Heberger et al. (2009) state that sea-level could rise 12-16 inches above current levels by 2050 and 23-55 inches by 2100. More recent studies project higher sea-level rise due to the melting of Antarctica and Greenland ice sheets (DeConto \& Pollard, 2016; NRC, 2011). Regardless, some extent of sea-level rise is “virtually certain” (Cooley et al., 2012).

In a recent report titled "Social Vulnerability to Climate Change in California,” Cooley et al. (2012) determines that sea-level rise will likely impact the coast of California in a variety of ways, including:

- Cliff failure resulting from coastal bluff erosion

- Dune erosion

- Higher storm surges and flood elevations during storms; increased flooding risk in lowlying areas with residential, commercial, energy, wastewater, and transportation infrastructure

- Permanent inundation of coastal wetlands; inland migration of wetland habitats

- Saltwater intrusion into freshwater wells used for agriculture and residential purposes

\subsection{Social Vulnerability}

The extent to which the impacts of sea-level rise may be adverse to coastal populations depends on their exposure and vulnerability. The International Panel on Climate Change (IPCC) defines exposure as "the inventory of elements in an area in which hazard events may occur" (2001, p. 69). Disaster 
risk only exists if people or structures are exposed to the hazard. However, exposed elements are not necessarily vulnerable. The IPCC (2001) defines vulnerability as "the propensity of exposed elements such as human beings, their livelihoods, and assets to suffer adverse effects when impacted by hazard events” (p. 70).

Social vulnerability is a function of a population's sensitivity and capacity to adapt to the short- and long-term effects of a hazard (Cooley et al., 2012; Moser \& Ekstrom, 2012). Social vulnerability is determined by a population's access to resources, political power and representation, social capital, beliefs and customs, building quality, physical ability, and density of infrastructure and support systems (Cutter, 2003). Indicators of social vulnerability include socioeconomic status, gender, race and ethnicity, age, commercial and industrial development, employment loss, rural/urban status, residential property, critical infrastructure, housing status, occupation, family structure, education, population growth, medical services, social dependence, and special needs population.

The most recent assessment of sea-level rise vulnerability in San Luis Obispo was a component of "Developing Adaptation Strategies For San Luis Obispo County: Preliminary Climate Change Vulnerability Assessment for Social Systems,” conducted by the Pacific Institute in 2011. As the report incorporates several impacts related to climate change, it does not provide a great amount of detail on coastal vulnerability. The report includes a map overlaying sea-level rise inundation zones with a social vulnerability index on the Census tract level, and a brief discussion of its implications. The authors suggest a need for a higher resolution map of social vulnerability, as the tract-level assessment is not exactly useful for identifying areas of priority for adaptation to sea-level rise (Moser \& Ekstrom, 2012). 


\section{METHODOLOGY}

In order to identify more specific areas exposed and vulnerable to sea-level rise hazards than what is provided at the tract-level, this study generated social vulnerability scores per Census block group using corresponding data from the 2015 American Community Survey. The block group is considered a more accurate and useful scale at which to assess social vulnerability to natural hazards, and is the highest possible resolution with available data for San Luis Obispo County (Moser \& Ekstrom, 2012; Martinich et al, 2011; Schmidtlein, 2008; Flanagan et al., 2011).

\subsection{Social Vulnerability Index}

The primary component of this study is to measure the social vulnerability within different areas of coastal San Luis Obispo County. The chosen method was to generate a Social Vulnerability Index for each Census block group, using data from the 2015 American Community Survey. The Social Vulnerability Index was developed by Cutter et al. (2003) and has since been a common method for measuring relative social vulnerability within a region (Cutter et al., 2003; Wilson et al., 2010; Nelson et al., 2015). The social vulnerability score is calculated using variables that are empirically predictive of social vulnerability. The selection of variables depends on data availability at the desired scale and, in the context of environmental hazards, relevance to the hazard of focus.

\subsection{Variable Selection}

Sea-level rise poses several hazards to human populations, including flooding from higher storm surges and expanded floodplains, dune erosion, coastal bluff erosion, wetland migration, and damaged infrastructure (Moser \& Ekstrom, 2012). Both the adverse effects of sea-level rise and the risk of those effects are prolonged for socially vulnerable communities, because they lack the capacity to adapt to changing conditions or, in other words, prevent harm to themselves in the future (CalEMA \& CNRA, 2012; Martinich et al., 2013). 
Thus, nearly all social vulnerability factors apply to sea-level rise, not just those which influence the immediate response to and recovery from hazards specific to sea-level rise. However, this study selected 37 variables most applicable to the region and available on the block-level, described in Table 2.1.

Table 2.1 Selected Variables for the Social Vulnerability Index

\begin{tabular}{|c|c|c|c|}
\hline & & & \\
\hline Indicator & Variables & Census Dataset & Sources \\
\hline & $\begin{array}{l}\text { Civilian labor force } \\
\text { unemployed } \\
\end{array}$ & B23025 & Cutter, Mitchell, and Scott, 2000; \\
\hline $\begin{array}{l}\text { Socioeconomic } \\
\text { status }\end{array}$ & $\begin{array}{l}\text { Extremely low-very low } \\
\text { income status }\end{array}$ & B17017 & $\begin{array}{l}\text { Blaikie et al., 1994; Peacock, } \\
\text { Morrow, and Gladwin, 1997, } \\
\text { 2000; Hewitt, 1997; Prasad, 2012; } \\
\text { Puente, 1999; Platt, 1999; Moser } \\
\text { \& Ekstrom, 2012. }\end{array}$ \\
\hline Gender & \% Female civilian employed & C24010 & $\begin{array}{l}\text { Blaikie et al., 1994; Cutter, 1996; } \\
\text { Enarson and Morrow, 1998; } \\
\text { Enarson and Scanlon, 1999; } \\
\text { Fothergill, 1996; Morrow and } \\
\text { Phillips,1999; Nelson et al., 2015; }\end{array}$ \\
\hline & \% Female ages $16-24$ & B01001 & $\begin{array}{l}\text { Peacock, Morrow, and Gladwin } \\
\text { 1997, 2000; Moser \& Ekstrom, } \\
\text { 2012; Hewitt,1997; }\end{array}$ \\
\hline & $\begin{array}{l}\% \text { Native American } \\
\text { population }\end{array}$ & B02001 & \\
\hline & \% Hispanic/Latino population & B03003 & \\
\hline Race and & $\begin{array}{l}\% \text { African American } \\
\text { population }\end{array}$ & В02001 & $\begin{array}{l}\text { Moser \& Ekstrom, 2012; Nelson et } \\
\text { al., 2015; Pulido, 2000; Peacock, } \\
\text { Morrow, and Gladwin. } 1997 .\end{array}$ \\
\hline ethr & \% Asian population & B02001 & 2000; Bolin with Stanford, 1998; \\
\hline & \% Some other race & & Bolin, 1993 \\
\hline & $\%$ Two or more races & & \\
\hline & $\begin{array}{l}\text { Limited English speaking } \\
\text { household }\end{array}$ & B16002 & \\
\hline & $\%$ population $<14$ years old & B01001 & $\begin{array}{l}\text { Cutter et al. 2003; Frigerio et al., } \\
\text { 2016; Morrow 1999; Moser \& }\end{array}$ \\
\hline Mge & $\%$ population $<5$ years old & B01001 & Ekstrom, 2012; Nelson et al., \\
\hline & $\%$ population $65+$ years old & B01001 & \\
\hline Transnortation & $\begin{array}{l}\text { Population using public } \\
\text { transportation to get to work }\end{array}$ & B08301 & Nelson et al 2015 \\
\hline 1 & $\begin{array}{l}\% \text { occupied housing units } \\
\text { with no vehicle available }\end{array}$ & B25044 & (2) \\
\hline The type, value, & $\%$ housing as mobile & B25024 & Heinz Center for Science, \\
\hline
\end{tabular}




\begin{tabular}{|c|c|c|c|}
\hline Indicator & Variables & Census Dataset & Sources \\
\hline $\begin{array}{l}\text { quality, and } \\
\text { density of } \\
\text { housing }\end{array}$ & $\begin{array}{l}\text { \% Owner-occupied housing } \\
\text { units with value less than } \\
50 \% \text { of median home value }\end{array}$ & B25075 & $\begin{array}{l}\text { Economics, and the Environment, } \\
\text { 2000; Bolin and Stanford, 1991; } \\
\text { Cutter, Mitchell, and Scott, 2000; } \\
\text { Moser \& Ekstrom, 2012; Nelson et } \\
\text { al., 2015. }\end{array}$ \\
\hline Housing status & $\begin{array}{l}\% \text { renter-occupied housing } \\
\text { units }\end{array}$ & B25003 & $\begin{array}{l}\text { Heinz Center for Science, } \\
\text { Economics, and the Environment, } \\
\text { 2000; Moser \& Ekstrom, 2012; } \\
\text { Nelson et al., } 2015 .\end{array}$ \\
\hline \multirow{5}{*}{ Occupations } & \% employed in agriculture & \multirow{5}{*}{ C24010 } & \multirow{5}{*}{$\begin{array}{l}\text { Heinz Center for Science, } \\
\text { Economics, and the Environment, } \\
\text { 2000; Moser \& Ekstrom, } 2012 .\end{array}$} \\
\hline & $\begin{array}{l}\text { \% employed in service } \\
\text { industry }\end{array}$ & & \\
\hline & $\begin{array}{l}\text { \% employed in transportation } \\
\text { industry }\end{array}$ & & \\
\hline & \% employed in construction & & \\
\hline & \% employed in maintenance & & \\
\hline \multirow{3}{*}{ Household size } & \% single-parent households & \multirow{3}{*}{ B11001 } & \multirow{3}{*}{$\begin{array}{l}\text { Heinz Center for Science, } \\
\text { Economics, and the Environment, } \\
\text { 2000; Moser \& Ekstrom, } 2012 .\end{array}$} \\
\hline & \# people per household & & \\
\hline & $\begin{array}{l}\text { Crowding \% (>1 person per } \\
\text { room) }\end{array}$ & & \\
\hline Education level & $\begin{array}{l}\text { Population over } 25 \text { without } \\
\text { high school diploma }\end{array}$ & B15003 & $\begin{array}{l}\text { Heinz Center for Science, } \\
\text { Economics, and the Environment, } \\
\text { 2000; Moser \& Ekstrom, } 2012 .\end{array}$ \\
\hline \multirow{2}{*}{$\begin{array}{l}\text { Regions with } \\
\text { rapid population } \\
\text { growth }\end{array}$} & New residents in past year & B07201 & \multirow{2}{*}{$\begin{array}{l}\text { Cutter, Mitchell, and Scott, Heinz } \\
\text { Center for Science, Economics, } \\
\text { and the Environment, 2000; 2000; } \\
\text { Morrow, 1999; Moser \& Ekstrom, } \\
\text { 2012; Puente, 1999. }\end{array}$} \\
\hline & $\%$ foreign residents & B99051 & \\
\hline \multirow{3}{*}{$\begin{array}{l}\text { Dependence on } \\
\text { social services }\end{array}$} & $\begin{array}{l}\text { Civilian labor force } \\
\text { unemployed }\end{array}$ & B23025 & \multirow{3}{*}{$\begin{array}{l}\text { Morrow, 1999; Heinz Center for } \\
\text { Science, Economics, and the } \\
\text { Environment, 2000; Drabek, 1996; } \\
\text { Hewitt, 2000; Moser \& Ekstrom, } \\
\text { 2012; Nelson et al., } 2015 .\end{array}$} \\
\hline & $\begin{array}{l}\text { \% households with social } \\
\text { security income }\end{array}$ & B19055 & \\
\hline & $\begin{array}{l}\text { Households receiving food } \\
\text { stamps in past } 12 \text { months }\end{array}$ & B22010 & \\
\hline \multirow{2}{*}{$\begin{array}{l}\text { Populations with } \\
\text { special needs } \\
\text { (infirm, } \\
\text { institutionalized, } \\
\text { transient, and } \\
\text { homeless) }\end{array}$} & \% with a disability, age $20-64$ & B23024 & \multirow[b]{2}{*}{$\begin{array}{l}\text { Morrow, 1999; Moser \& Edstrom, } \\
\text { 2012; Nelson et al., 2015; Tobin } \\
\text { and Ellenberger, 1993. }\end{array}$} \\
\hline & $\begin{array}{l}\text { \% population in group } \\
\text { quarters }\end{array}$ & B09019 & \\
\hline
\end{tabular}

\subsection{Statistical Analysis}

The process of formulating the social vulnerability index begins with a principle components analysis using SPSS Statistical Software, which generates a smaller subset of vulnerability factors from all 37 possible factors listed in Table 2.1 (Cutter et al., 2003; Flanagan et al., 2011; Nelson 
et al., 2015). The purpose of the principle components analysis is to convert a set of observations of potentially correlated variables into a set of linearly uncorrelated variables called "principle components." In other words, this technique extracts the most important information from the data table and expresses it as a set of new variables. The principle components analysis is used in exploratory data analysis and for creating predictive models.

Using guidance from Cutter et al. (2003), Flanagan et al. (2011), and Nelson et al. (2015), the following steps were followed to derive the most suitable number of components and the corresponding scores for each block group.

1) Remove all block groups with a population of zero.

2) Convert all observations into percentages of the total value of each variable's respective universe (e.g. total population, total households, total housing units, etc.).

3) Standardize data using SPSS Statistical Software (involves converting all values to Zscores, where the mean of all observations within each variable is equal to zero).

4) Conduct a principle components analysis on the standardized data. See Appendix A for SPSS output correspondent to the steps below.

a. The output of the principle components analysis resulted in 12 components, which cumulatively explain $73 \%$ of the variance. Despite the high variance explained by 12 components, it is difficult to describe each one based on the highest loading variables. As such, it is necessary to reduce the number of components such that each can be clearly described and differentiated from the other based on factor loadings.

b. Through examination of the scree plot, which shows the relationship between number of components and variance explained, the determination was to extract five components in the final round of the principle components analysis. 
c. Each component is given a descriptive name commensurate with the highest factor loadings, summarized in Table 2.2 Note that a factor loading $<0.5$ is considered significant in this study, but the description of the component is based on the three highest factors.

d. See Appendix A for the SPSS output correspondent to this final round of the principle components analysis.

5) The principle components analysis generated component scores for each block group, which were then put into an additive model to calculate the social vulnerability score. All selected variables empirically have a positive correlation with social vulnerability, so an absolute value was applied to all component scores before the final social vulnerability score was calculated. The component scores and the total social vulnerability score for each block can be found in Appendix B.

Table 2.2 Components and Highest Factor Loadings

\begin{tabular}{|c|c|}
\hline Component & Highest factor loadings \\
\hline (1) Language and Ethnicity & $\begin{array}{l}\text { \% Hispanic/Latino (.885) } \\
\% \text { foreign born }(.819) \\
\% \text { limited English speaking household (.808) } \\
\% \text { age } 25+\text { without a high school diploma }(.789) \\
\%>1 \text { occupants per room }(.780) \\
\text { \% some other race }(.770) \\
\% \text { single-parent household }(.525) \\
\% \text { farming, fishing, and forestry occupation }(.522) \\
\% \text { household size } 5+\text { people }(.514)\end{array}$ \\
\hline (2) Household Status & $\begin{array}{l}\text { \% 10+ units in structure (.756) } \\
\text { \% different house in U.S. } 1 \text { year ago (.747) } \\
\text { \% in group quarters (.733) } \\
\text { \% female between } 16-25 \text { (.696) } \\
\text { \% very to extremely low income (.659) } \\
\text { \% renter-occupied (.618) } \\
\text { \% occupied housing units with no vehicle available (.596) }\end{array}$ \\
\hline
\end{tabular}




\begin{tabular}{|l|l|}
\hline & \% less than 14 years old (.527) \\
\hline \multirow{3}{*}{ (3) Age and Social Isolation } & $\begin{array}{l}\text { \% 65+ years old (.820) } \\
\text { \% receives social security income (.795) } \\
\text { \% mobile homes (.601) }\end{array}$ \\
\hline \multirow{3}{*}{$\begin{array}{l}\text { (4) Dependence on Social } \\
\text { Services }\end{array}$} & $\begin{array}{l}\text { \% population between 20-64 with a disability (.627) } \\
\text { \% households with supplemental security income (.624) }\end{array}$ \\
\hline & \% received food stamps in past year (.575) \\
\hline (5) Race and Occupation & \% Installation, maintenance, and repair occupation (.643) \\
& \% Construction and extraction occupation (.526) \\
& \% less than 5 years old (.519)
\end{tabular}

\subsection{Geospatial Analysis}

After the scores were generated using SPSS Statistical Processing Software, the next step was to map them in Geographic Information Systems. A new geospatial dataset was created in GIS by joining the social vulnerability scores with the geographic boundaries of block groups retrieved from the U.S. Census. Since the social vulnerability score is mapped by block group, building footprints are included to indicate where the population is located. This is especially helpful in large rural block groups, which is most of the County. The social vulnerability map was then overlaid with the most recent sea-level rise hazard layers to illustrate how it can be used for planning purposes.

For visual purposes, an additional layer was created by spatially joining the parcel dataset with the block-level social vulnerability scores. Through this process, the parcels are simply given the values of the social vulnerability score of the block in which they are located. This technique is used to maintain concise and consistent boundaries. If there is more than one block adjoining the parcel, it is given the average score. The block-level social vulnerability score is still provided to compare with the "parcel-level” social vulnerability score. 


\section{RESULTS}

The social vulnerability score for every coastal block group is ranked by standard deviation and highlighted in Figure 4.1. As an example of how these geospatial datasets can be used for further research and planning in the County, Figures 4.2-4.8 illustrate the social vulnerability of each unincorporated coastal community (also referred to as Urban or Village Reserve Lines). Findings for each coastal community are organized by the four coastal planning areas: (1) North Coast, (2) Estero, (3) San Luis Bay Coast, and (4) South County Coast. Each of these planning areas have separate "area plans" that are extensions of the County Land Use and Circulation Element and certified by the California Coastal Commission as local coastal programs. The geospatial datasets provided by other sources to improve the usefulness of the social vulnerability map are described in Appendix C.

For the purposes of illustrating both the usefulness and limitations of assessing social vulnerability to sea-level rise at the block group level, social vulnerability and building stock are overlaid with existing geospatial datasets for sea-level rise hazards (described in Appendix C). As mentioned previously in this report, the boundaries of Census block groups are not as precise as the boundaries of sea-level rise hazards, as well as other natural hazards (Nelson et al., 2015). However, block groups are higher resolution than Census tracts, which is the scale of the social vulnerability assessment currently available to the County.

\subsection{North Coast Planning Area}

The North Coast Planning Area includes the following coastal communities: San Simeon (Village Reserve Line) and Cambria (Urban Reserve Line).

\section{- San Simeon}

Figure 4.2 indicates very high social vulnerability throughout the San Simeon Village Reserve Line, as well as exposure to increased inundation risk due to sea-level rise. 
- Cambria

Figure 4.3 indicates high to very high social vulnerability within the Cambria Urban Reserve Line, as well as exposure to increased risk of bluff erosion due to sea-level rise.

\subsection{Estero Planning Area}

The Estero Planning Area includes the following coastal communities: Cayucos (Urban Reserve Line) and Los Osos (Urban Reserve Line).

- Cayucos

Figure 4.4 indicates moderate to very high social vulnerability in the Cayucos Urban Reserve Line, as well possible exposure to increased risk of inundation, bluff erosion, and wetland migration.

- Los Osos

Figure 4.5 indicates moderate to high social vulnerability, as well as potential exposure to increased risk of inundation and wetland migration.

\subsection{San Luis Bay Coastal Planning Area}

The San Luis Bay Coastal Planning Area includes the following coastal communities: Avila Beach (Urban Reserve Line) and Oceano (Urban Reserve Line).

- Avila Beach

Figure 4.6 indicates moderate to very low to very high social vulnerability, as well as potential exposure to increased risk of inundation, wetland migration, dune erosion, and bluff erosion.

- Oceano

Figure 4.7 indicates moderate to very high social vulnerability, as well as potential exposure to increased risk of inundation, wetland migration, and dune erosion. 


\subsection{South County Coastal Planning Area}

The South County Coastal Planning Area includes one coastal community, Callendar-Garrett Village Reserve Line. Although Callendar-Garrett is located within a coastal planning area, it is located far from any foreseeable hazards induced by sea-level rise. However, as mentioned before, the boundaries of these projected hazards may change in the future. Figure 4.8 indicates moderate-high social vulnerability within the Callendar-Garrett community, and no potential exposure to sea-level rise hazards based on presently available data. 


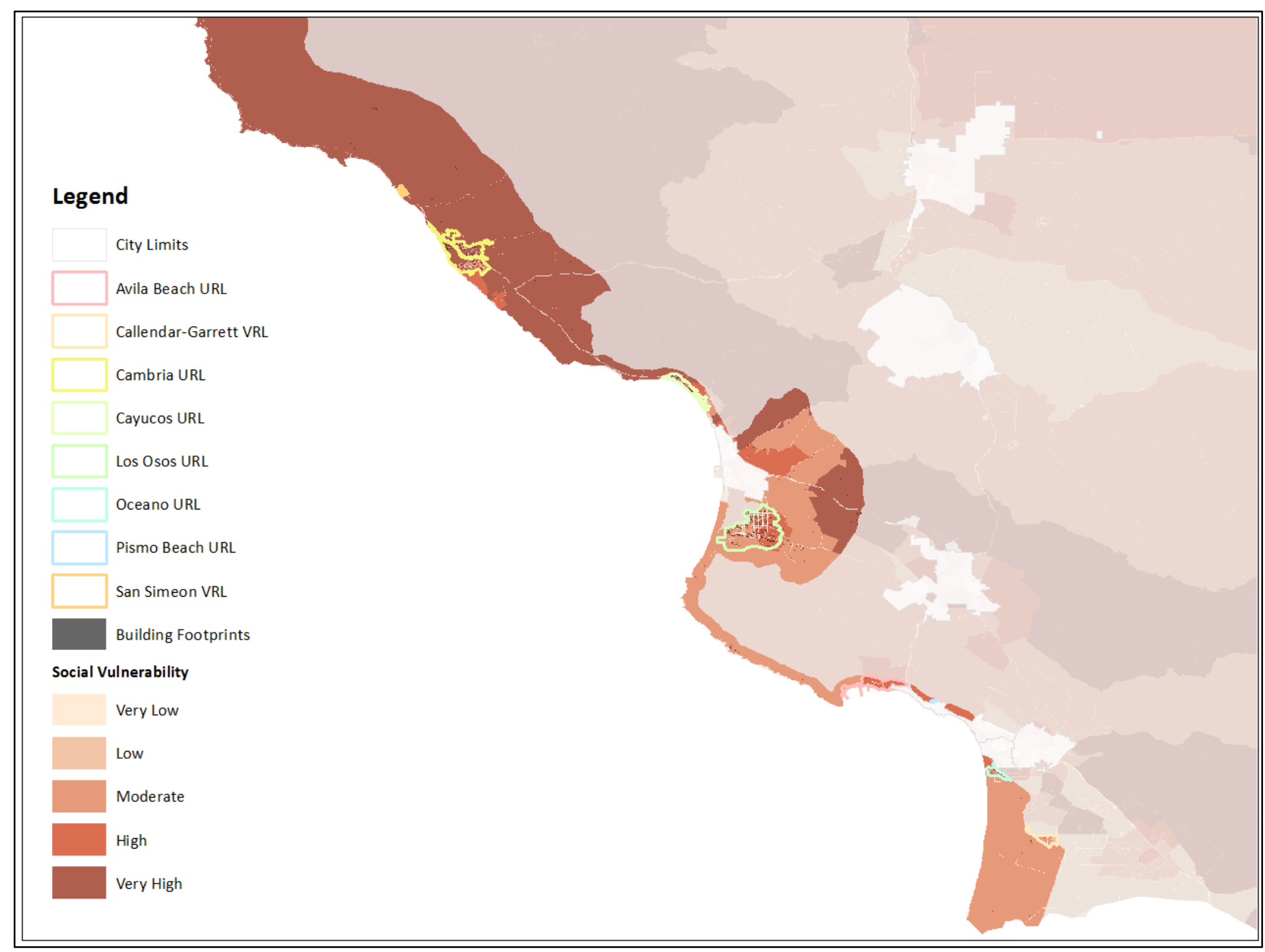

Figure 4.1 Social Vulnerability in San Luis Obispo County 


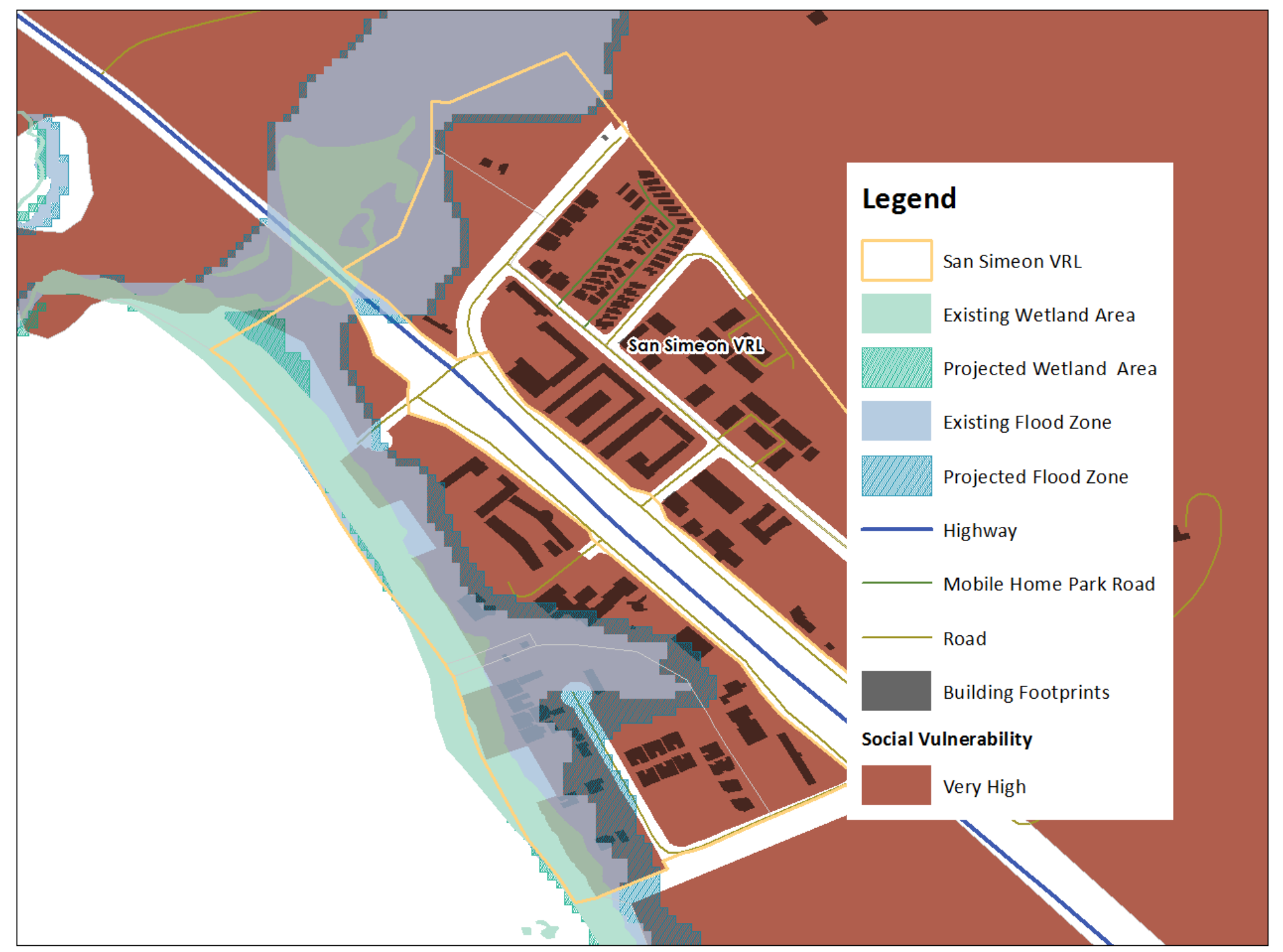

Figure 4.2 Social Vulnerability in San Simeon 


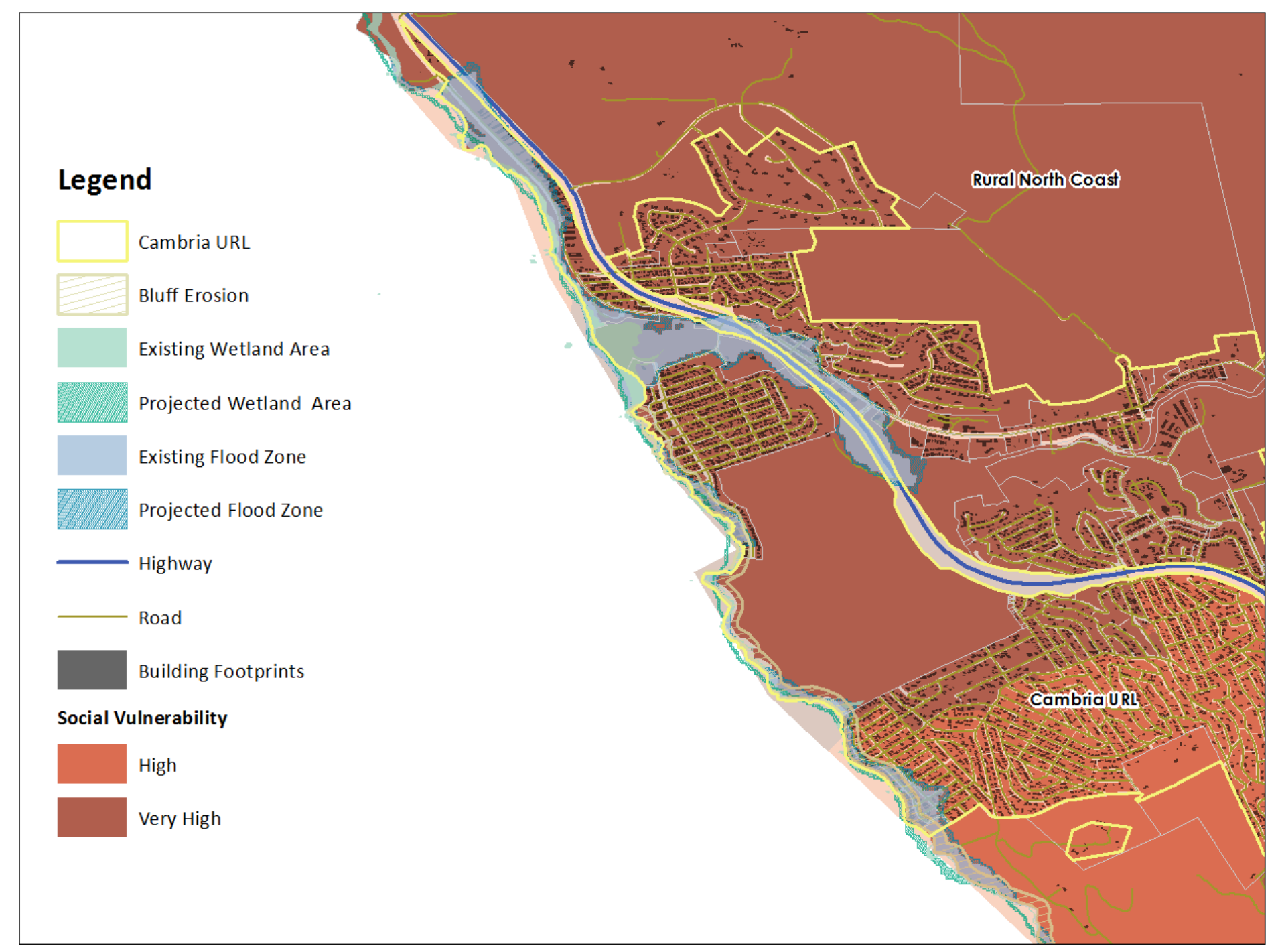

Figure 4.3 Social Vulnerability in Cambria 


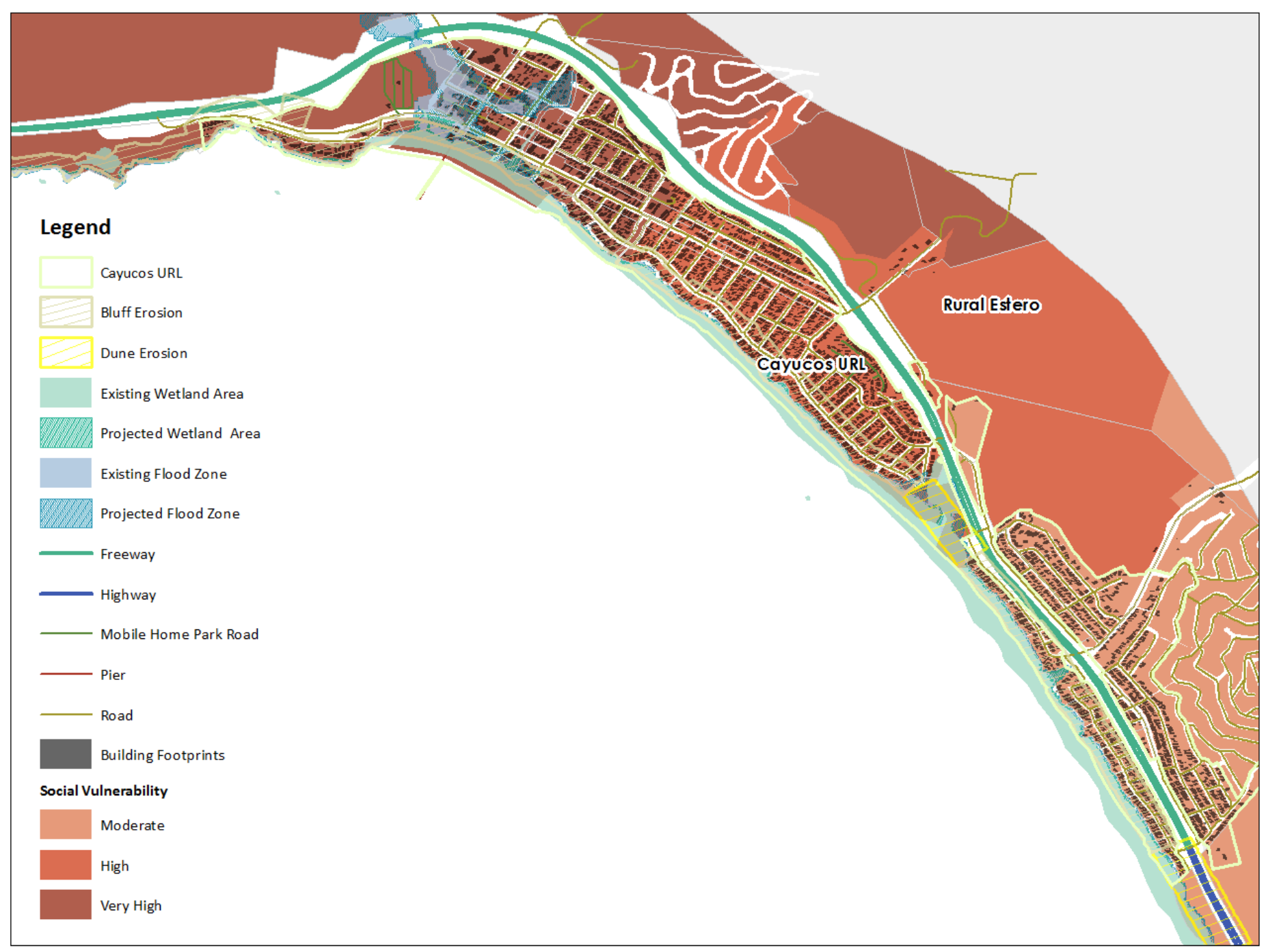

Figure 4.4 Social Vulnerability in Cayucos 


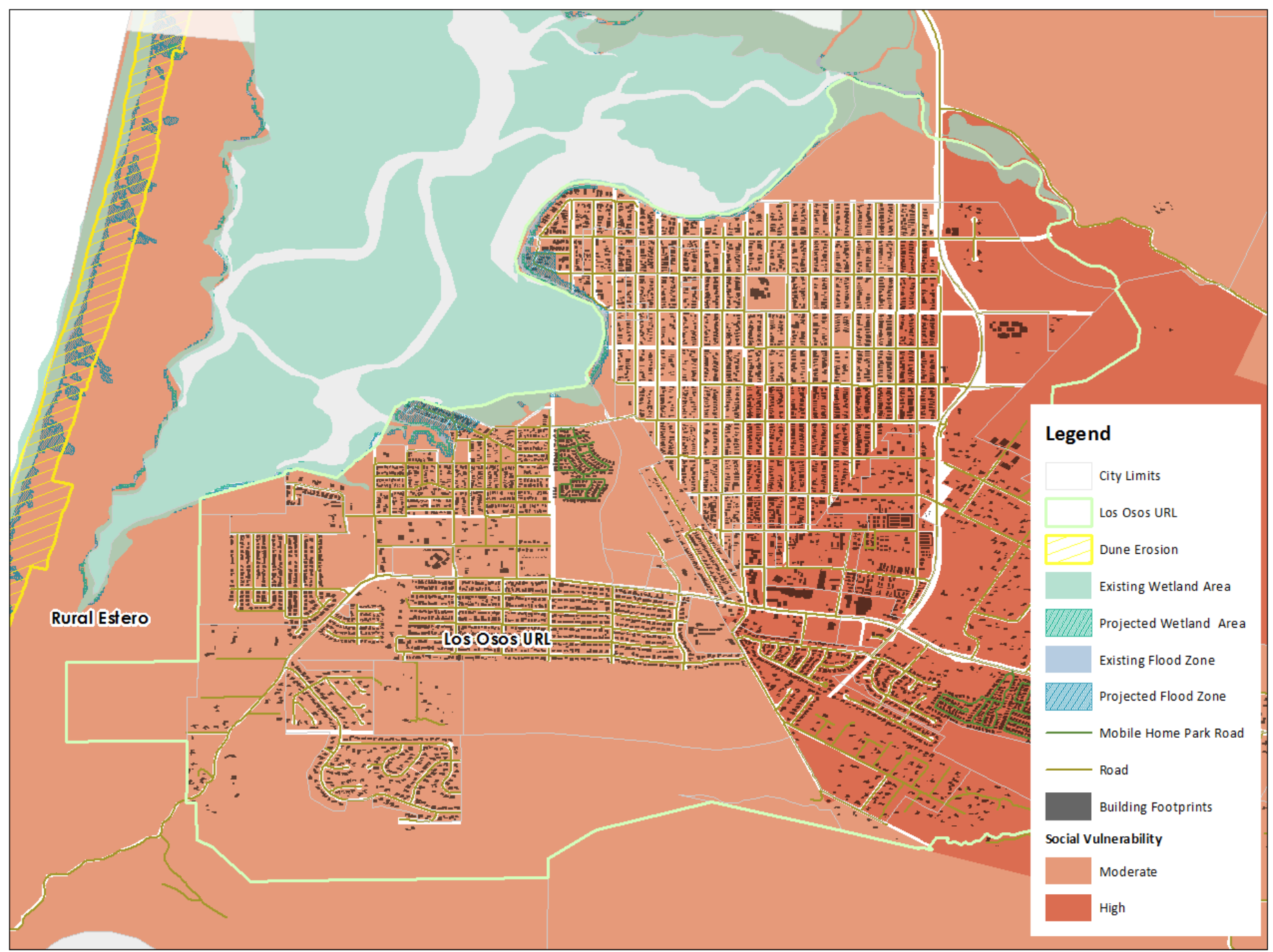

Figure 4.5 Social Vulnerability in Los Osos 


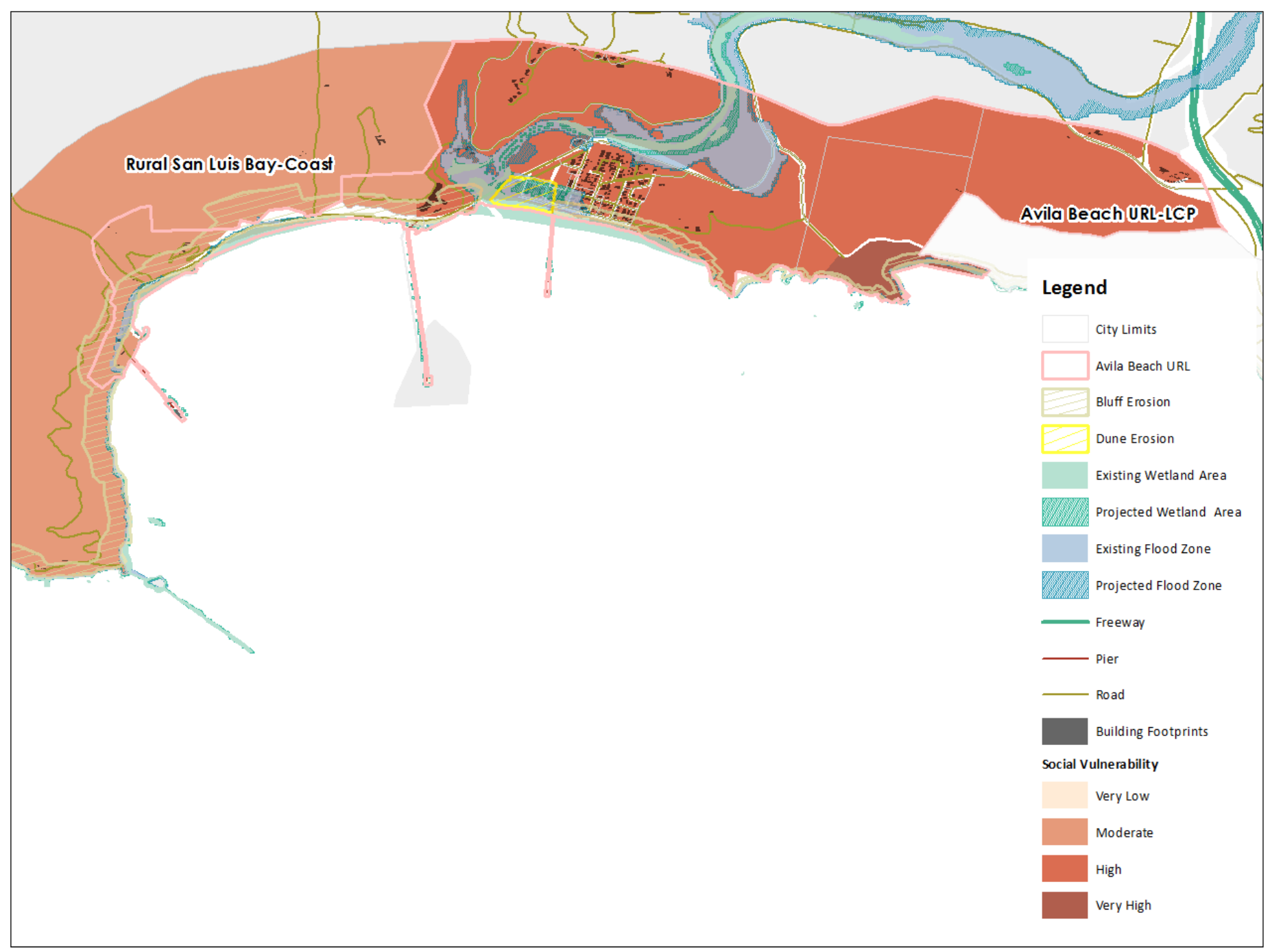

Figure 4.6 Social Vulnerability in Avila Beach 


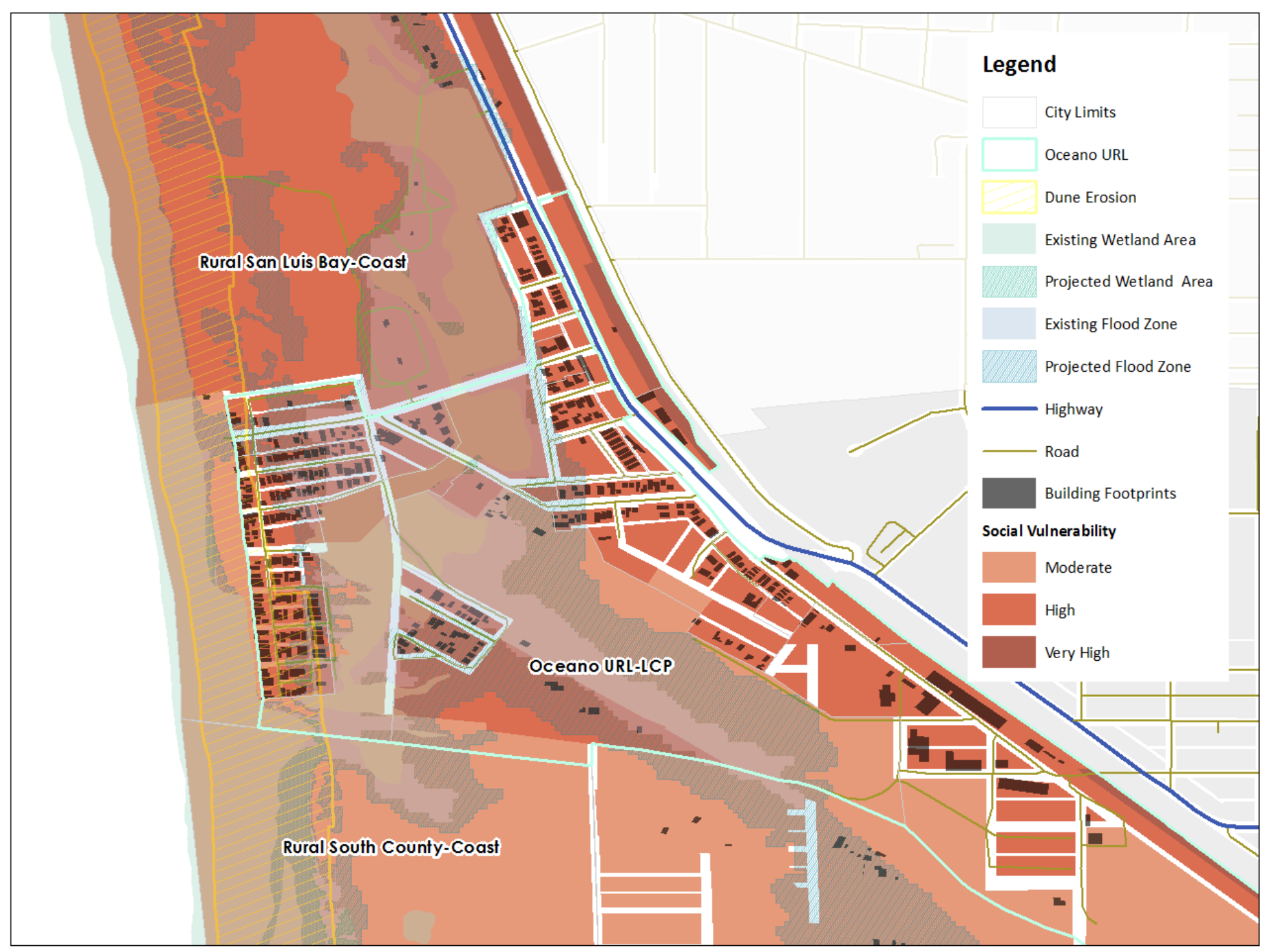

Figure 4.7 Social Vulnerability in Oceano 


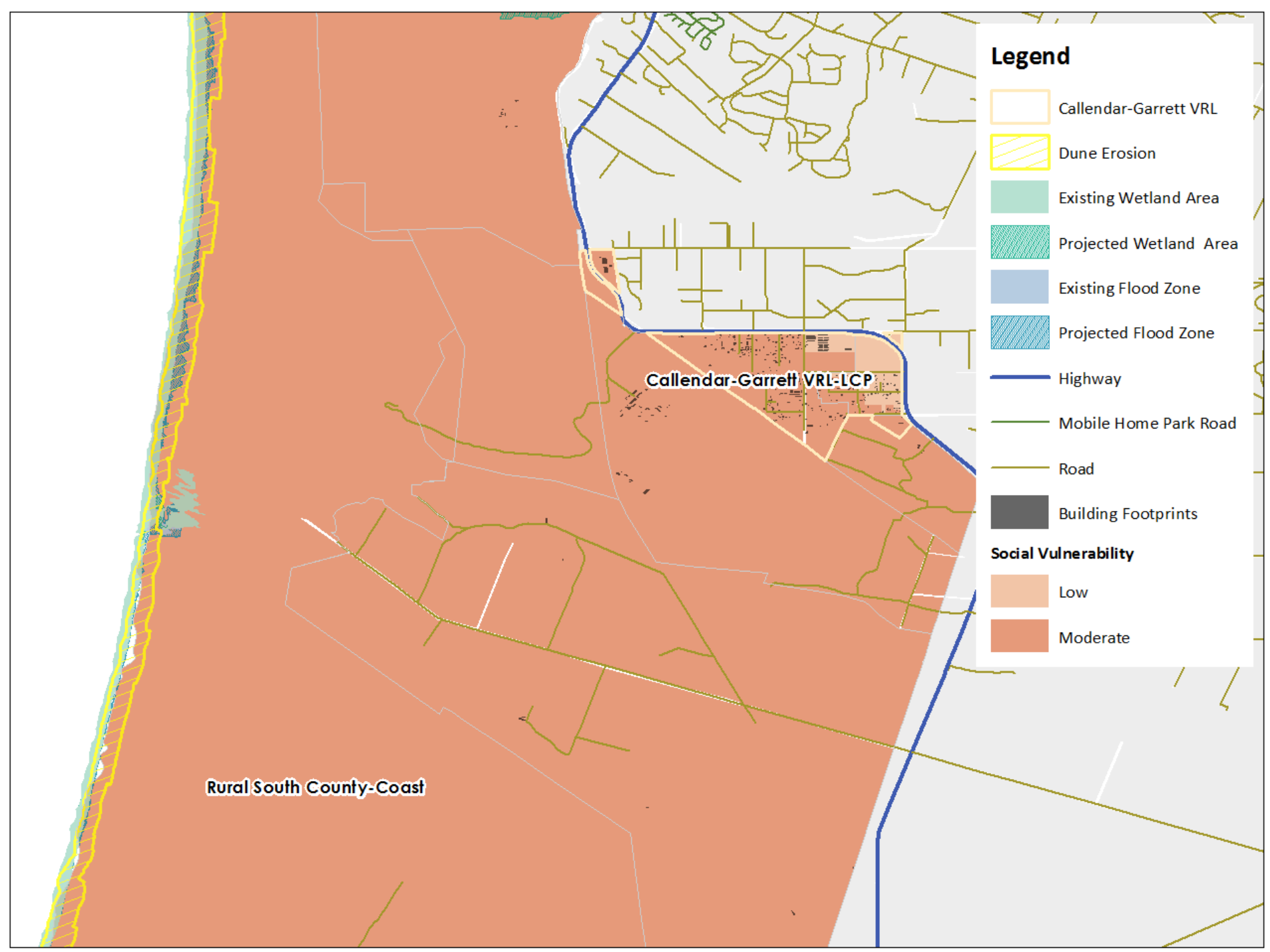

Figure 4.8 Social Vulnerability in Callendar-Garrett 


\section{POLICY IMPLICATIONS}

The intention of this study is to identify areas of priority for coastal adaptation to sea-level rise in San Luis Obispo County. As mentioned before, SB 379 requires the safety element or the local hazard mitigation plan to include an assessment of vulnerability to hazards induced or exacerbated by climate change. SB 1000 requires that the general plan includes an environmental justice element, which identifies disadvantaged communities and describes policies to address inequities in health and safety. The California Coastal Commission recently developed a guidance document for agencies to address sea-level rise in their local coastal program(s), which is most directly related to the findings of this study. The geospatial social vulnerability assessment in this study can be directly applied to future updates to the safety element, local hazard mitigation plan, and local coastal plans.

\subsection{General Plan Safety Element}

The Safety Element does not currently address the populations and assets most vulnerable to sealevel rise. The following table includes suggestions for each relevant section of the existing Safety element, to be considered for future updates to the General Plan.

Table 5.1 Recommendations for the Safety Element

\begin{tabular}{|l|ll|}
\hline \multicolumn{1}{|c|}{ Section } & \multicolumn{1}{c|}{ Recommendation } \\
\hline $\begin{array}{l}\text { Emergency } \\
\text { Preparedness }\end{array}$ & $\begin{array}{l}\text { Include policy to address the long-term and slow-moving impacts of } \\
\text { sea-level rise on critical infrastructure. Further research is needed to } \\
\text { determine which critical infrastructure will need to be relocated or } \\
\text { retrofitted. }\end{array}$ \\
\hline $\begin{array}{l}\text { W. } \\
\text { Water }\end{array}$ & $\begin{array}{l}\text { Include policy and update map to address the expansion of the 100- } \\
\text { year flood zone by 2050 and 2100. Further research is needed to } \\
\text { determine more precise boundaries of the projected flood zone during a } \\
\text { given year in the future }\end{array}$ \\
& $\begin{array}{l}\text { Include policy and map to address flooding and other safety issues } \\
\text { exacerbated by the inland migration of wetlands. }\end{array}$ \\
\hline
\end{tabular}




\begin{tabular}{|l|ll|}
\hline & \multicolumn{1}{|c|}{ impacts of tsunamis on different areas of the County. } \\
\hline $\begin{array}{l}\text { 5e } \\
\text { Geologic } \\
\text { Hazards }\end{array}$ & $\bullet \begin{array}{l}\text { Include map to address the expanded coastal bluff erosion area } \\
\text { projected in 2100. }\end{array}$ \\
\hline \begin{tabular}{l} 
6. $\begin{array}{l}\text { Other Safety } \\
\text { Issues }\end{array}$ \\
\hline $\begin{array}{l}\text { Sections 2, } \\
3,5 \text { and 6 }\end{array}$
\end{tabular} & $\begin{array}{l}\text { Add section on dune erosion, including mitigation policies for } \\
\text { buildings and infrastructure }\end{array}$ \\
\hline
\end{tabular}

\subsection{General Plan Land Use Element and Local Coastal Programs}

The County's General Plan Land Use Element for the Coastal Zone (last revised in 2011) is separated by four planning areas: Estero, North Coast, San Luis Bay Coastal, and South County Coastal. Local coastal programs for each planning area are incorporated into their respective land use elements. The California Coastal Commission recently provided guidance for agencies to address sea-level rise in Local Coastal Programs. This study partially fulfills the recommend step to identify the potential sea-level rise impacts in the Local Coastal Program planning area, which involves a vulnerability assessment.

The primary areas of concern are those in which proposed residential, commercial, industrial, public facilities, and critical infrastructure overlap with flood, erosion, or wetland migration zones. An updated Land Use and Circulation Element was proposed in 2013 and has yet to be adopted by the County; thus, the land uses illustrated in the map below do not reflect those which may be adopted within the coming years. Regardless, the following are recommendations for the updated General Plan Land Use and Circulation elements for the coastal planning areas:

- Ensure consistency with the Safety element: avoid land uses such as residential, commercial, industrial, public facilities, and critical infrastructure in the projected 100year flood, erosion, and wetland migration zones projected. 
- Consider designating areas within the hazard zones as open space

- Conduct further research to ensure an appropriate buffer between the hazard zones and high-intensity land uses 


\section{AREAS OF FUTURE RESEARCH}

The following section discusses potential areas of research to build upon this study. The geospatial vulnerability assessment should be overlaid with more accurate sea-level rise projections, as well as expanded to include other types of vulnerability.

\subsection{Sea-Level Rise Hazards}

If local sea-level hazards are assessed with better accuracy in the future, San Luis Obispo County can overlay those geospatial datasets with the social vulnerability map created in this study. The areas with the greatest need for climate adaptation strategies are those in which social vulnerability and hazard exposure overlap. Although determining the extent and probability of sea-level rise hazards is not the focus of this study, it is a necessary step towards a more complete vulnerability assessment.

\subsection{Social Vulnerability}

Another potentially useful way to expand upon this study is to develop a higher resolution social vulnerability map than at the block-level. A parcel-level social vulnerability assessment is possible by disaggregating Census block-level data to the parcel level using cadastral-informed selective disaggregation logic (Nelson et al., 2015). The resulting high-resolution map allows for a more accurate portrayal of social vulnerability than is provided by block-level data, particularly in the context of environmental hazards; the spatial boundaries of physical impacts induced by sea-level rise are much more precise than the boundaries of a Census block. The ancillary parcel data required to perform disaggregation were not available at the time of this study, but could potentially be obtained for future studies.

\subsection{Physical Vulnerability}

The maps generated by this study imply that different impacts of sea-level rise may warrant the relocation or retrofitting of certain physical assets, possibly entire networks. This study does not, however, provide a detailed analysis to inform the timing of those decisions. Further research is 
needed to inform the prioritization of capital improvement projects associated with adaptation to sea-level rise.

\subsection{Economic Vulnerability}

The economic impacts of sea-level rise may be felt beyond those populations and assets located on the coast. A more complete vulnerability assessment would further understand the economic sectors dependent on coastal resources, and how they will be affected by sea-level rise. In the 2012 study (cited earlier in this paper) "Developing Adaptation Strategies for San Luis Obispo County: Preliminary Climate Change Vulnerability Assessment for Social Systems,” Moser and Ekstrom broadly discuss how climate change will affect certain economic sectors, but does not provide an in-depth analysis of the economic impacts of sea-level rise. Nonetheless, both studies may provide the foundation for future analysis on sea-level rise vulnerability. 


\section{REFERENCES}

Bergstrand, K., Mayer, B., Brumback, B., \& Zhang, Y. (2015). Assessing the Relationship Between Social Vulnerability and Community Resilience to Hazards. Social Indicators Research, 122(2), 391-409. doi:10.1007/s11205-014-0698-3

Berke, P., Newman, G., Lee, J., Combs, T., Kolosna, C., \& Salvesen, D. (2015). Evaluation of Networks of Plans and Vulnerability to Hazards and Climate Change: A Resilience Scorecard. Journal of The American Planning Association, 81(4), 287-302. doi:10.1080/01944363.2015.1093954

Blake, P., T. Cannon, I. Davis, and B. Wisner. 1994. At Risk: Natural Hazards, People’s Vulnerability, and Disasters. London: Routledge.

Bolin, R. 1993. Household and Community Recovery After Earthquakes. Boulder, Colo.: Institute of Behavioral Science, University of Colorado.

Bolin, R., and L. Stanford. 1991. "Shelter, Housing and Recovery: A Comparison of US Disasters.” Disasters 15(1):24-34.

—. 1998. The Northridge Earthquake: Vulnerability and Disaster. London: Routledge.

Burton, I., R. W. Kates, and G. F. White. 1993. The Environment as Hazard (2nd ed.). New York: Guildford.

California Air Resources Board. (2014). Assembly Bill 32 Overview. Retrieved from https://www.arb.ca.gov/cc/ab32/ab32.htm

California Natural Resources Agency and California Emergency Management Agency. (2012). California Adaptation Planning Guide: Identifying Adaptation Strategies. Retrieved from http://resources.ca.gov/docs/climate/APG_Identifying_Adaptation_Strategies.pdf

Cooley, H., E. Moore, M. Heberger, and L. Allen (Pacific Institute). (2012). Social Vulnerability to Climate Change in California. California Energy Commission. Publication Number: CEC500-2012-013.

Cutter, S. L., \& Finch, C. (2008). Temporal and spatial changes in social vulnerability to natural hazards. Proceedings of The National Academy of Sciences of The United States of America, 105(7), 2301-2306. doi:10.1073/pnas.0710375105

Cutter, S. L., Boruff, B. J., \& Shirley, W. L. (2003). Social vulnerability to environmental hazards. Social Science Quarterly, 84, 242-261. doi:10.1111/1540-6237.8402002. 
Cutter, S. L., Mitchell, J. T., \& Scott, M. S. (2000). Revealing the Vulnerability of People and Places: A Case Study of Georgetown County, South Carolina. Annals of The Association of American Geographers, 90(4), 713.

Cutter, S. (1996). “Vulnerability to Environmental Hazards.” Progress in Human Geography 20(4):529-39.

Dash, N., McCoy, B. G., \& Herring, A. (2010). Class. In B. D. Phillips, D. S. K. Thomas, A. Fothergill, \& L. Blinn-Pike (Eds.), Social vulnerability to disasters (pp. 75-100). Boca Raton, FL: CRC Press.

Deconto, R. , \& Pollard, D. (2016). Contribution of Antarctica to past and future sea-level rise. Nature, 531(7596), 591.

de Oliveira Mendes, J. M. (2009). Social vulnerability indexes a planning tools: Beyond the preparedness paradigm. Journal of Risk Research, 12, 43-58.

Drabek, T. E. 1996. Disaster Evacuation Behavior: Tourists and Other Transients. Program on Environment and Behavior Monograph No. 58, Institute of Behavioral Science. Boulder, Colo.: University of Colorado.

Environmental Protection Agency (EPA). (2016). Adapting to Climate Change. Retrieved from https://www.epa.gov/climatechange/adapting-climate-change

Felsenstein, D. , \& Lichter, M. (2014). Social and economic vulnerability of coastal communities to sea-level rise and extreme flooding. Natural Hazards, 71(1), 463-491.

Federal Emergency Management Agency. (2008). A Tutorial on Emergency Management, Broadly Defined, Past, and Present. Retrieved from https:/training.fema.gov/hiedu/docs/terms\%20and\%20definitions/terms\%20and\%20definitio ns.pdf

Flanagan, B. , Gregory, E. , Hallisey, E. , Heitgerd, J. , \& Lewis, B. (2011). A social vulnerability index for disaster management. Journal of Homeland Security and Emergency Management, 8(1), 1792.

Frigerio, I., Ventura, S., Strigaro, D., Mattavelli, M., De Amicis, M., Mugnano, S., \& Boffi, M. (2016). A GIS-based approach to identify the spatial variability of social vulnerability to seismic hazard in Italy. Applied Geography, 7412-22. doi:10.1016/j.apgeog.2016.06.014

Heberger, M., H. Cooley, P. Herrera, P. H. Gleick, and E. Moore. (2009). The Impacts of Sealevel Rise on the California Coast. Prepared by the Pacific Institute for the California Climate Change Center.

Heinz Center for Science, Economics, and the Environment. (2000). The Hidden Costs of Coastal Hazards: Implications for Risk Assessment and Mitigation. Covello, Cal.: Island Press.

— (2002). Human Links to Coastal Disasters. Washington, D.C.: The H. John Heinz III Center for Science, Economics and the Environment.

International Panel on Climate Change. (2001). Climate Change Summary for Policymakers. 
Hewitt, K. (1997). Regions of Risk: A Geographical Introduction to Disasters. Essex, U.K.: Longman.

International Federation of Red Cross (IFRC). (n.d.). "What is a disaster?”. Retrieved from http://www.ifrc.org/en/what-we-do/disaster-management/about-disasters/what-is-a-disaster/

Land, K. C. 1983. “Social Indicators.”’ Annual Review of Sociology 9:1-26.

Martinich, J. , Neumann, J. , Ludwig, L. , \& Jantarasami, L. (2013). Risks of sea-level rise to disadvantaged communities in the united states. Mitigation and Adaptation Strategies for Global Change, 18(2), 169-185.

Maris, F., Kitikidou, K., Paparrizos, S., Karagiorgos, K., Potouridis, S., \& Fuchs, S. (2015). Regional Hazard Analysis For Use In Vulnerability And Risk Assessment. Quaestiones Geographicae, 34(3), 77-84. doi:10.1515/quageo-2015-0026

Mileti, D. 1999. Disasters by Design: A Reassessment of Natural Hazards in the United States. Washington, D.C.: Joseph Henry Press.

Mitchell, J. K., ed. 1999. Crucibles of Hazard: Mega-Cities and Disasters in Transition. Tokyo: United Nations University Press.

Morrow, B. H. 1999. “'Identifying and Mapping Community Vulnerability.” Disasters 23(1):1118.

Morrow, B. H., and B. Phillips. 1999. “What's Gender 'Got to Do With It'?”' International Journal of Mass Emergencies and Disasters 17(1):5-11.

Moser, Susanne C., Julia Ekstrom. (Susanne Moser Research \& Consulting, Santa Cruz and University of California, Berkeley). (2012). DEVELOPING ADAPTATION STRATEGIES FOR SAN LUIS OBISPO COUNTY: Preliminary Climate Change Vulnerability Assessment for Social Systems. California Energy Commission. Publication number: CEC-500-2012-054.

Nelson, K. S., Abkowitz, M. D., \& Camp, J. V. (2015). A method for creating high resolution maps of social vulnerability in the context of environmental hazards. Applied Geography, 6389-100. doi:10.1016/j.apgeog.2015.06.011

Ngo, E. B. 2001. “'When Disasters and Age Collide: Reviewing Vulnerability of the Elderly.” Natural Hazards Review 2(2):80-89.

Peacock, W., B. H. Morrow, and H. Gladwin, eds. 1997. Hurricane Andrew and the Reshaping of Miami: Ethnicity, Gender, and the Socio-Political Ecology of Disasters. Gainesville, Fla.: University Press of Florida.

— 2000. Hurricane Andrew and the Reshaping of Miami: Ethnicity, Gender, and the SocioPolitical Ecology of Disasters. Miami, Fla.: Florida International University, International Hurricane Center.

Prasad, S. (2012). An Assessment of Human Vulnerability to Hazards in the US Coastal Northeast and mid-Atlantic. Southeastern Geographer, 52(3), 282-298. 
Puente, S. 1999. “Social Vulnerability to Disaster in Mexico City." Pp. 295-334 in J. K. Mitchell, ed., Crucibles of Hazard: Mega-Cities and Disasters in Transition. Tokyo: United Nations University Press.

Pulido, L. 2000. “Rethinking Environmental Racism: White Privilege and Urban Development in Southern California.”' Annals of the Association of American Geographers 90:12-40.

Putnam, R. D. 2000. Bowling Alone: Collapse and Revival of the American Community. New York: Simon \& Schuster.

Rossi, R. J., and K. J. Gilmartin. 1980. The Handbook of Social Indicators: Sources, Characteristics and Analysis. New York: Garland STPM Pres

San Luis Obispo County. 2011. Coastal Framework for Planning - Land Use Element . Retrieved from http://www.slocounty.ca.gov/Assets/PL/Elements/CZframework.pdf

—. 2014. Safety Element. Retrieved from http://www.slocounty.ca.gov/Assets/PL/Elements/Safety+Element.pdf

Schmidtlein M, Deutsch R, Piegorsch W, Cutter S (2008) A sensitivity analysis of the social vulnerability index. Rsk Anal 28(4):1099-1114

Tobin, G. A., and J. C. Ollenburger. 1993. Natural Hazards and the Elderly. Boulder, Colo.: University of Colorado, Natural Hazards Research and Applications Information Center. 


\section{APPENDICES}

\section{APPENDIX A: SPSS Output from Principle Components Analysis}

The first round of the principle components analysis helps us determine the number of components to extract for the final principle components analysis. The output from the first round is given in the tables and figures below.

\section{KMO and Bartlett's Test}

Kaiser-Meyer-Olkin Measure of Sampling Adequacy. $\quad .755$

Bartlett's Test of Sphericity Approx. Chi-Square 3075.218

\begin{tabular}{ll} 
df & 666 \\
\hline Sig. & .000 \\
\hline
\end{tabular}

\section{Total Variance Explained}

Initial Eigenvalue

Extraction Sums of Squared Loadings $\quad$ Rotation Sums of Squared Loadings

\begin{tabular}{|c|c|c|c|c|c|c|c|c|c|}
\hline Component & Total & $\%$ of Variance & Cumulative \% & Total & $\%$ of Variance & Cumulative \% & Total & $\%$ of Variance & Cumulative \% \\
\hline 1 & 6.736 & 18.207 & 18.207 & 6.736 & 18.207 & 18.207 & 5.529 & 14.942 & 14.942 \\
\hline 2 & 4.884 & 13.201 & 31.407 & 4.884 & 13.201 & 31.407 & 3.223 & 8.711 & 23.653 \\
\hline 3 & 2.360 & 6.378 & 37.785 & 2.360 & 6.378 & 37.785 & 2.656 & 7.179 & 30.833 \\
\hline 4 & 2.268 & 6.130 & 43.916 & 2.268 & 6.130 & 43.916 & 2.632 & 7.113 & 37.946 \\
\hline 5 & 2.134 & 5.767 & 49.682 & 2.134 & 5.767 & 49.682 & 2.014 & 5.443 & 43.389 \\
\hline 6 & 1.642 & 4.438 & 54.121 & 1.642 & 4.438 & 54.121 & 1.923 & 5.196 & 48.585 \\
\hline 7 & 1.411 & 3.814 & 57.934 & 1.411 & 3.814 & 57.934 & 1.906 & 5.151 & 53.735 \\
\hline 8 & 1.239 & 3.350 & 61.284 & 1.239 & 3.350 & 61.284 & 1.862 & 5.032 & 58.768 \\
\hline 9 & 1.193 & 3.223 & 64.507 & 1.193 & 3.223 & 64.507 & 1.496 & 4.043 & 62.811 \\
\hline 10 & 1.094 & 2.958 & 67.465 & 1.094 & 2.958 & 67.465 & 1.316 & 3.558 & 66.369 \\
\hline
\end{tabular}




\begin{tabular}{|c|c|c|c|c|c|c|c|c|c|}
\hline 11 & 1.077 & 2.911 & 70.377 & 1.077 & 2.911 & 70.377 & 1.260 & 3.404 & 69.773 \\
\hline 12 & 1.003 & 2.711 & 73.088 & 1.003 & 2.711 & 73.088 & 1.226 & 3.314 & 73.088 \\
\hline 13 & .930 & 2.514 & 75.602 & & & & & & \\
\hline 14 & .865 & 2.339 & 77.941 & & & & & & \\
\hline 15 & .736 & 1.989 & 79.930 & & & & & & \\
\hline 16 & .701 & 1.894 & 81.823 & & & & & & \\
\hline 17 & .663 & 1.793 & 83.616 & & & & & & \\
\hline 18 & .644 & 1.741 & 85.357 & & & & & & \\
\hline 19 & .569 & 1.538 & 86.895 & & & & & & \\
\hline 20 & .533 & 1.441 & 88.336 & & & & & & \\
\hline 21 & .496 & 1.340 & 89.676 & & & & & & \\
\hline 22 & .429 & 1.159 & 90.835 & & & & & & \\
\hline 23 & .410 & 1.109 & 91.945 & & & & & & \\
\hline 24 & .367 & .993 & 92.938 & & & & & & \\
\hline 25 & .334 & .902 & 93.840 & & & & & & \\
\hline 26 & .300 & .811 & 94.651 & & & & & & \\
\hline 27 & .266 & .719 & 95.371 & & & & & & \\
\hline 28 & .253 & 682 & 96.053 & & & & & & \\
\hline 29 & .240 & .650 & 96.703 & & & & & & \\
\hline 30 & .218 & .590 & 97.293 & & & & & & \\
\hline 31 & .206 & .558 & 97.850 & & & & & & \\
\hline 32 & .189 & .510 & 98.361 & & & & & & \\
\hline 33 & .168 & .454 & 98.815 & & & & & & \\
\hline 34 & .141 & .381 & 99.196 & & & & & & \\
\hline 35 & .121 & .327 & 99.523 & & & & & & \\
\hline
\end{tabular}




\begin{tabular}{l|l|l|l|l|l|l|l|l|}
\hline 36 & .096 & .258 & 99.781 & & & \\
\hline 37 & .081 & .219 & 100.000 & & & \\
\hline
\end{tabular}

Extraction Method: Principal Component Analysis.

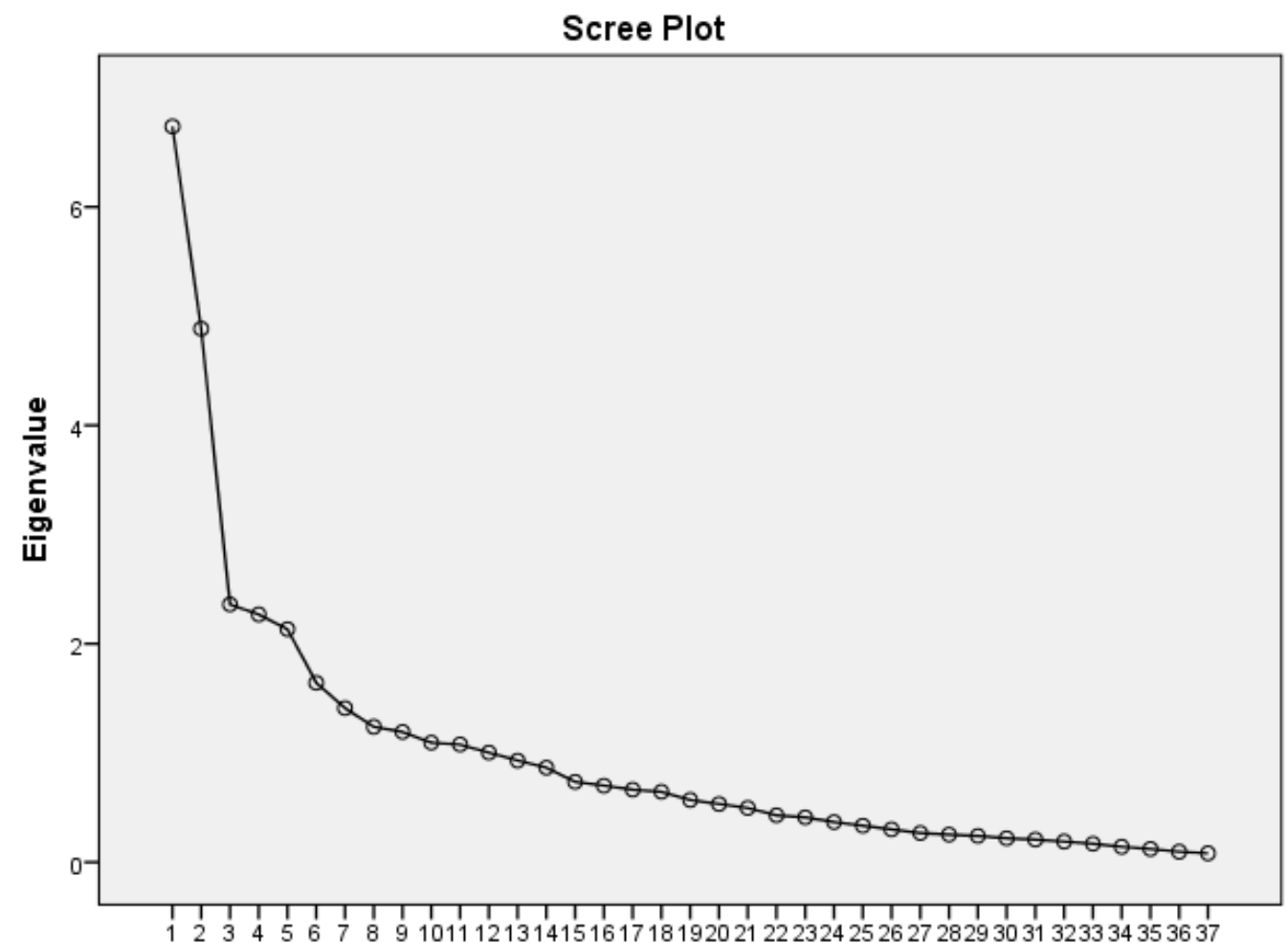

Component Number 


\section{Rotated Component Matrix ${ }^{\mathrm{a}}$}

\begin{tabular}{|c|c|c|c|c|c|c|c|c|c|c|c|c|}
\hline & \multicolumn{12}{|c|}{ Component } \\
\hline & 1 & 2 & 3 & 4 & 5 & 6 & 7 & 8 & 9 & 10 & 11 & 12 \\
\hline Zscore: Foreign born & .882 & .041 & -.153 & .083 & -.010 & -.019 & -.018 & -.051 & -.034 & .133 & .040 & -.085 \\
\hline Zscore: Hispanic/Latino & .863 & .091 & -.021 & .137 & .139 & -.017 & .067 & .044 & .125 & -.070 & .067 & .083 \\
\hline $\begin{array}{l}\text { Zscore: Limited English } \\
\text { Speaking Household }\end{array}$ & .820 & .104 & -.144 & .115 & .036 & -.014 & .015 & -.014 & -.054 & -.106 & .132 & -.082 \\
\hline $\begin{array}{l}\text { Zscore: Occupants per } \\
\text { room \&gt; } 1 \text { for all } \\
\text { tenure statuses }\end{array}$ & .792 & .010 & .169 & .078 & .179 & -.034 & -.066 & .023 & .122 & -.023 & -.096 & .034 \\
\hline $\begin{array}{l}\text { Zscore: Some other } \\
\text { race }\end{array}$ & .732 & .010 & .106 & .053 & -.001 & -.040 & .174 & -.029 & .243 & -.106 & -.015 & .002 \\
\hline $\begin{array}{l}\text { Zscore: Population } \\
\text { \&gt;25 without H.S. } \\
\text { diploma }\end{array}$ & .727 & .063 & .056 & -.121 & .098 & .099 & .436 & .114 & -.034 & -.157 & .030 & .026 \\
\hline $\begin{array}{l}\text { Zscore: Single-parent } \\
\text { household }\end{array}$ & .532 & -.008 & -.118 & .187 & .058 & .281 & .020 & .320 & .252 & -.004 & -.278 & .080 \\
\hline $\begin{array}{l}\text { Zscore: Received Food } \\
\text { Stamps in Past Year }\end{array}$ & .477 & .291 & -.157 & -.055 & .062 & .059 & .255 & .291 & .448 & .087 & -.160 & .126 \\
\hline $\begin{array}{l}\text { Zscore: Service } \\
\text { Occupations: Food, } \\
\text { Personal, Grounds, } \\
\text { Maintenance, } \\
\text { \&amp;Healthcare }\end{array}$ & .472 & .469 & -.054 & -.028 & -.074 & -.329 & -.143 & .061 & -.044 & .081 & -.207 & -139 \\
\hline
\end{tabular}




\begin{tabular}{|c|c|c|c|c|c|c|c|c|c|c|c|c|}
\hline $\begin{array}{l}\text { Zscore: Extremely and } \\
\text { Very Low Income } \\
\text { (\&lt;50\% AMI) }\end{array}$ & .156 & .833 & .210 & .072 & -.121 & -.041 & -.039 & .066 & .065 & .055 & -.018 & -.013 \\
\hline Zscore: Renter-occupied & .217 & .726 & .180 & .448 & -.029 & .050 & .085 & .133 & .016 & .118 & -.034 & -.089 \\
\hline $\begin{array}{l}\text { Zscore: Occupied } \\
\text { housing units with no } \\
\text { vehicle available }\end{array}$ & -.036 & .683 & .074 & -.101 & -.100 & -.048 & .358 & .034 & .037 & .098 & -.119 & .127 \\
\hline $\begin{array}{l}\text { Zscore: } 10+\text { Units in } \\
\text { Structure }\end{array}$ & -.052 & .648 & .442 & .266 & -.082 & .144 & .023 & -.124 & .009 & .082 & -.005 & .028 \\
\hline $\begin{array}{l}\text { Zscore: Population in } \\
\text { group quarters }\end{array}$ & -.004 & .094 & .873 & .067 & -.156 & -.003 & .197 & -.075 & .054 & -.064 & -.025 & .034 \\
\hline $\begin{array}{l}\text { Zscore: Different house } \\
\text { in U.S. } 1 \text { year ago }\end{array}$ & -.081 & .390 & .735 & .119 & -.068 & -.116 & .001 & -.074 & -.035 & -.013 & -.039 & .078 \\
\hline $\begin{array}{l}\text { Zscore: Female between } \\
16-25\end{array}$ & -.035 & -.406 & -.608 & .137 & -.058 & .011 & -.019 & .281 & -.004 & -.255 & -.072 & .194 \\
\hline Zscore: $65+$ years old & -.181 & -.117 & -.138 & -.855 & -.207 & .073 & -.088 & -.010 & -.122 & -.014 & .024 & -.070 \\
\hline $\begin{array}{l}\text { Zscore: Receives Social } \\
\text { Security Income }\end{array}$ & -.112 & -.294 & -.067 & -.845 & -.215 & .049 & -.025 & -.056 & .027 & .055 & -.054 & .025 \\
\hline Zscore: Mobile Homes & -.089 & .133 & .069 & -.653 & .285 & -.173 & -.063 & .144 & .012 & -.144 & .178 & -.045 \\
\hline Zscore: \&lt; 5 years old & .197 & -.102 & -.194 & .140 & .675 & .326 & -.034 & .024 & .030 & -.051 & -.090 & -.015 \\
\hline $\begin{array}{l}\text { Zscore: \&lt; } 14 \text { years } \\
\text { old }\end{array}$ & .380 & -.315 & -.306 & .239 & .609 & .086 & .037 & .015 & .098 & -.079 & -.085 & .100 \\
\hline $\begin{array}{l}\text { Zscore: Household Size } \\
\text { 5+ people }\end{array}$ & .448 & -.235 & .008 & .167 & .546 & -.230 & -.062 & -.058 & .037 & .161 & -.009 & -.112 \\
\hline $\begin{array}{l}\text { Zscore: Construction } \\
\text { and Extraction }\end{array}$ & .014 & -.078 & .040 & -.302 & .489 & .281 & -.082 & .225 & -.172 & -.163 & .294 & .306 \\
\hline
\end{tabular}




\begin{tabular}{|c|c|c|c|c|c|c|c|c|c|c|c|c|}
\hline $\begin{array}{l}\text { Zscore: Native } \\
\text { Hawaiian and Other } \\
\text { Pacific Islander alone }\end{array}$ & -.053 & .048 & .055 & -.055 & .210 & .839 & -.049 & .029 & -.065 & .008 & -.054 & -.128 \\
\hline $\begin{array}{l}\text { Zscore: Installation, } \\
\text { maintenance, repair }\end{array}$ & -.001 & -.046 & -.096 & .050 & -.035 & .788 & .076 & .018 & .025 & -.045 & .085 & .036 \\
\hline $\begin{array}{l}\text { Zscore: Black or } \\
\text { African American Alone }\end{array}$ & -.018 & .122 & .133 & .159 & -.143 & -.011 & .776 & -.097 & .079 & .037 & -.042 & -.156 \\
\hline $\begin{array}{l}\text { Zscore: Farming, } \\
\text { Fishing, and Forestry } \\
\text { Occupations }\end{array}$ & .406 & -.043 & .305 & .044 & .071 & -.008 & .620 & .019 & -.162 & -.157 & .242 & -.032 \\
\hline $\begin{array}{l}\text { Zscore: Received public } \\
\text { assistance income in the } \\
\text { last year }\end{array}$ & .245 & .098 & -.147 & .024 & .086 & .114 & .556 & .286 & -.084 & .151 & -.144 & .212 \\
\hline $\begin{array}{l}\text { Zscore: Households } \\
\text { With Supplemental } \\
\text { Security Income (SSI) }\end{array}$ & .063 & .060 & .014 & -.081 & .106 & .164 & .017 & .810 & .079 & .074 & -.130 & -.105 \\
\hline $\begin{array}{l}\text { Zscore: Population } \\
\text { between 20-64, all } \\
\text { income levels with a } \\
\text { disability }\end{array}$ & -.011 & .014 & -.208 & .033 & -.077 & -.123 & .021 & .799 & .049 & -.022 & .092 & .105 \\
\hline $\begin{array}{l}\text { Zscore: Transportaton } \\
\text { and Materials Moving }\end{array}$ & .203 & -.025 & .084 & .032 & .062 & -.049 & -.028 & .098 & .828 & -.053 & .053 & -.036 \\
\hline $\begin{array}{l}\text { Zscore: In Civilian } \\
\text { Labor Force and } \\
\text { Unemployed, Age 16+ }\end{array}$ & .252 & .302 & -.240 & .220 & -.232 & .043 & -.101 & .015 & .424 & -.015 & .114 & .082 \\
\hline
\end{tabular}




\begin{tabular}{|c|c|c|c|c|c|c|c|c|c|c|c|c|}
\hline $\begin{array}{l}\text { Zscore: Uses public } \\
\text { transportation }\end{array}$ & -.055 & .175 & -.019 & .041 & -.084 & -.048 & .111 & .038 & -.099 & .641 & .033 & .061 \\
\hline $\begin{array}{l}\text { Zscore: American } \\
\text { Indian and Alaska } \\
\text { Native alone }\end{array}$ & .213 & -.052 & .015 & .044 & -.302 & .020 & .070 & .070 & -.331 & -.535 & -.032 & .025 \\
\hline Zscore: Asian & .020 & .004 & .401 & .195 & -.297 & .023 & -.233 & .194 & -.160 & .525 & -.048 & .160 \\
\hline $\begin{array}{l}\text { Zscore: Lacking } \\
\text { Complete Plumbing } \\
\text { Facilities }\end{array}$ & .046 & -.111 & -.037 & -.069 & -.040 & .046 & -.019 & -.049 & .071 & .053 & .884 & -.039 \\
\hline $\begin{array}{l}\text { Zscore: Two or More } \\
\text { Races }\end{array}$ & -.029 & .016 & .030 & .054 & .010 & -.069 & -.040 & .005 & .013 & .093 & -.040 & .905 \\
\hline
\end{tabular}

Extraction Method: Principal Component Analysis.

Rotation Method: Varimax with Kaiser Normalization.

$$
\text { a. Rotation converged in } 11 \text { iterations. }
$$

The output from the second round of principle components analysis is given below.

\section{KMO and Bartlett's Test}

Kaiser-Meyer-Olkin Measure of Sampling Adequacy.

Bartlett's Test of Sphericity Approx. Chi-Square

.755

\begin{tabular}{l|l} 
df & 666 \\
\hline Sig. & .000 \\
\hline
\end{tabular}




\section{Total Variance Explained}

\begin{tabular}{|c|c|c|c|c|c|c|c|c|c|}
\hline \multirow[b]{2}{*}{ Component } & \multicolumn{3}{|c|}{ Initial Eigenvalues } & \multicolumn{3}{|c|}{ Extraction Sums of Squared Loadings } & \multicolumn{3}{|c|}{ Rotation Sums of Squared Loadings } \\
\hline & Total & $\%$ of Variance & Cumulative \% & Total & \% of Variance & Cumulative \% & Total & $\%$ of Variance & Cumulative \% \\
\hline 1 & 6.736 & 18.207 & 18.207 & 6.736 & 18.207 & 18.207 & 6.161 & 16.651 & 16.651 \\
\hline 2 & 4.884 & 13.201 & 31.407 & 4.884 & 13.201 & 31.407 & 4.525 & 12.231 & 28.881 \\
\hline 3 & 2.360 & 6.378 & 37.785 & 2.360 & 6.378 & 37.785 & 2.729 & 7.375 & 36.256 \\
\hline 4 & 2.268 & 6.130 & 43.916 & 2.268 & 6.130 & 43.916 & 2.555 & 6.905 & 43.161 \\
\hline 5 & 2.134 & 5.767 & 49.682 & 2.134 & 5.767 & 49.682 & 2.413 & 6.521 & 49.682 \\
\hline 6 & 1.642 & 4.438 & 54.121 & & & & & & \\
\hline 7 & 1.411 & 3.814 & 57.934 & & & & & & \\
\hline 8 & 1.239 & 3.350 & 61.284 & & & & & & \\
\hline 9 & 1.193 & 3.223 & 64.507 & & & & & & \\
\hline 10 & 1.094 & 2.958 & 67.465 & & & & & & \\
\hline 11 & 1.077 & 2.911 & 70.377 & & & & & & \\
\hline 12 & 1.003 & 2.711 & 73.088 & & & & & & \\
\hline 13 & .930 & 2.514 & 75.602 & & & & & & \\
\hline 14 & .865 & 2.339 & 77.941 & & & & & & \\
\hline 15 & .736 & 1.989 & 79.930 & & & & & & \\
\hline 16 & .701 & 1.894 & 81.823 & & & & & & \\
\hline 17 & .663 & 1.793 & 83.616 & & & & & & \\
\hline 18 & .644 & 1.741 & 85.357 & & & & & & \\
\hline 19 & .569 & 1.538 & 86.895 & & & & & & \\
\hline 20 & .533 & 1.441 & 88.336 & & & & & & \\
\hline 21 & .496 & 1.340 & 89.676 & & & & & & \\
\hline 22 & .429 & 1.159 & 90.835 & & & & & & \\
\hline
\end{tabular}




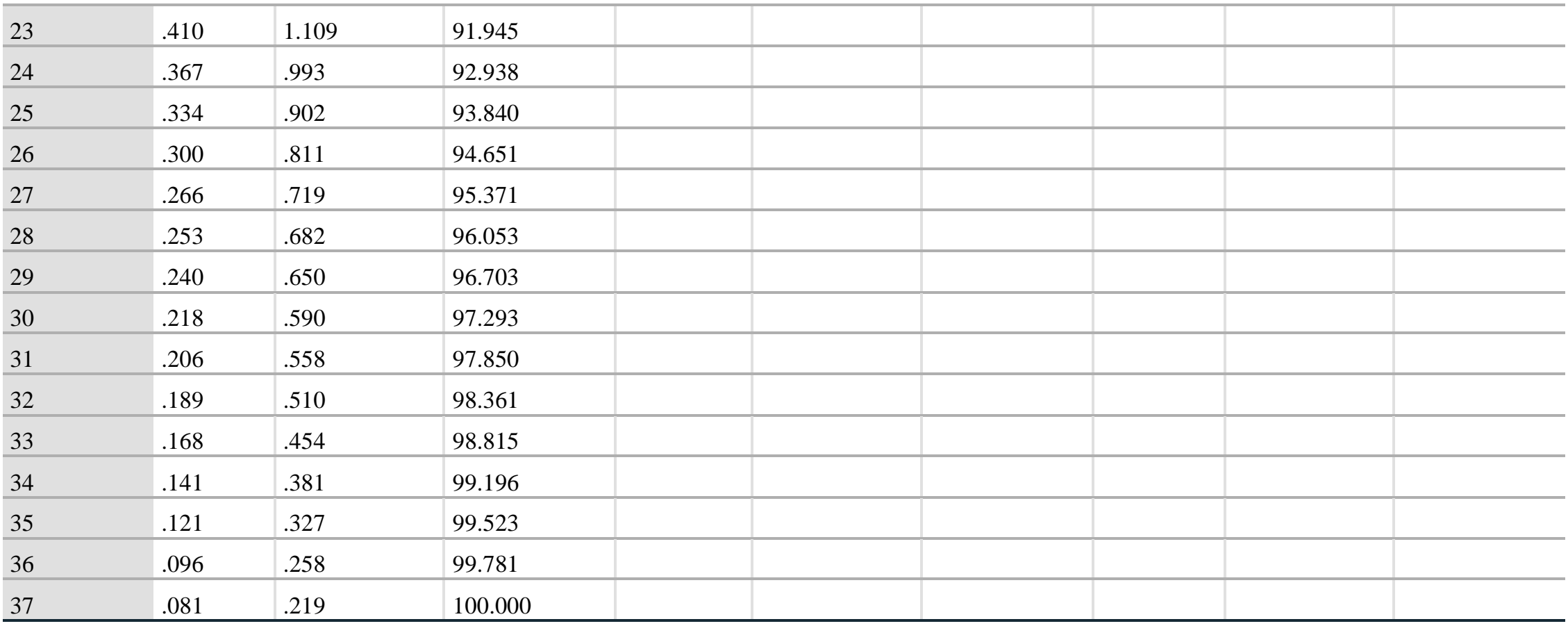

Extraction Method: Principal Component Analysis. 


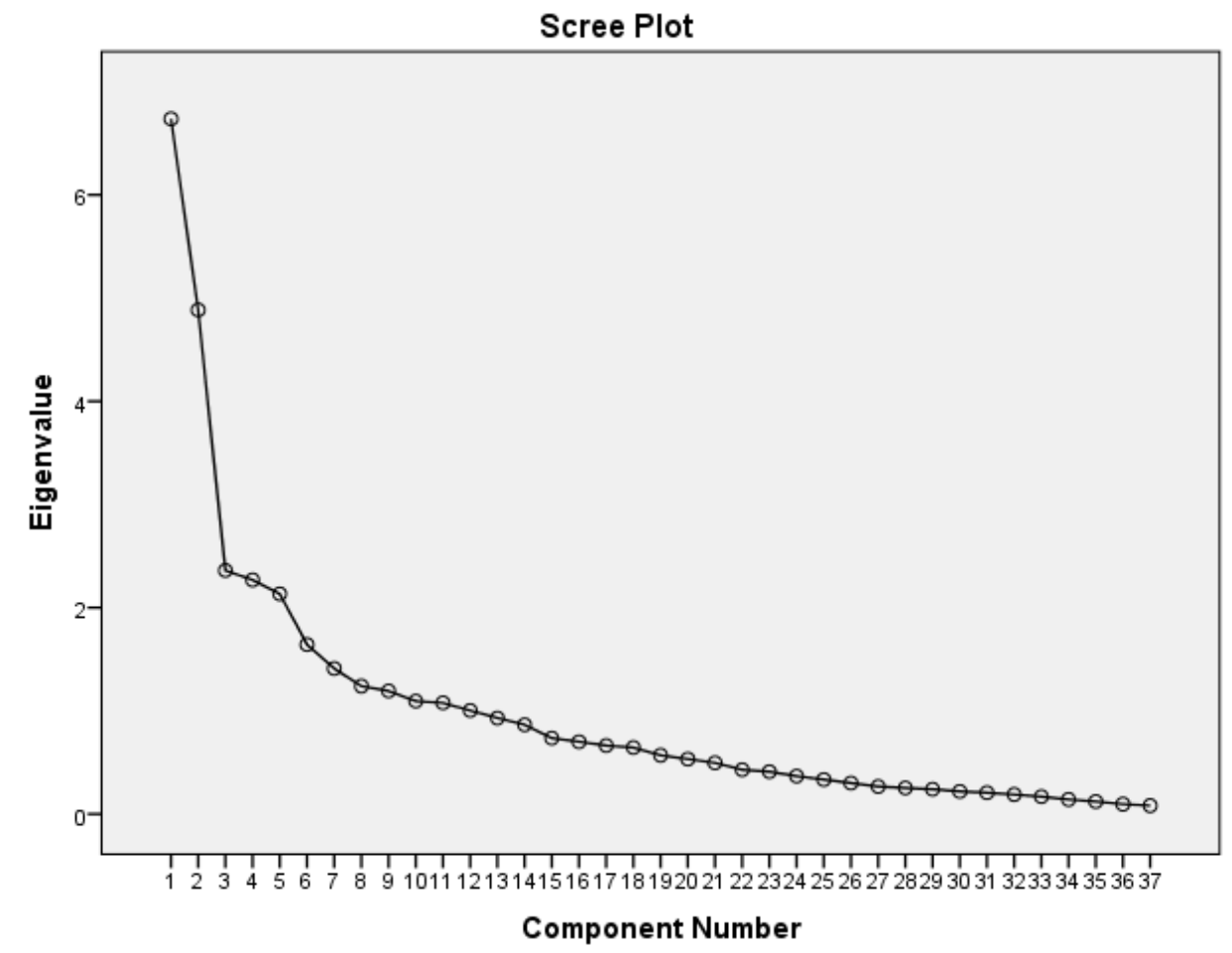

\section{Rotated Component Matrix ${ }^{\mathrm{a}}$}

\begin{tabular}{ll|l|l|l|l} 
& \multicolumn{2}{c}{ Component } & & & \\
& 1 & 2 & 3 & 4 & .076 \\
\hline Zscore: Hispanic/Latino & .885 & .005 & -.117 & .005 & -.130 \\
\hline Zscore: Foreign born & .819 & -.069 & -.082 & .035 & -.053 \\
\hline Zscore: Limited English Speaking Household & .808 & -.040 & -.057 & .004 & .251 \\
\hline Zscore: Population \&gt;25 without H.S. diploma & .789 & .166 & .230 & .060 & \\
\hline
\end{tabular}




\begin{tabular}{|c|c|c|c|c|c|}
\hline $\begin{array}{l}\text { Zscore: Occupants per room \&gt; } 1 \text { for all tenure } \\
\text { statuses }\end{array}$ & .780 & .033 & -.126 & -.011 & -.024 \\
\hline Zscore: Some other race & .770 & .099 & -.010 & -.007 & -.038 \\
\hline Zscore: Single-parent household & .525 & -.127 & -.221 & .417 & .230 \\
\hline $\begin{array}{l}\text { Zscore: Farming, Fishing, and Forestry } \\
\text { Occupations }\end{array}$ & .522 & .358 & .172 & -.245 & .278 \\
\hline Zscore: Household Size 5+ people & .514 & -.274 & -.255 & -.231 & -.011 \\
\hline Zscore: Transportaton and Materials Moving & .317 & -.059 & -.085 & .181 & -.096 \\
\hline Zscore: American Indian and Alaska Native alone & .179 & .041 & .161 & -.104 & .035 \\
\hline Zscore: $10+$ Units in Structure & -.056 & .756 & -.321 & .082 & -.006 \\
\hline Zscore: Different house in U.S. 1 year ago & -.081 & .747 & -.137 & -.135 & -.122 \\
\hline Zscore: Population in group quarters & .009 & .733 & -.010 & -.283 & .038 \\
\hline Zscore: Female between 16-25 & -.021 & -.696 & -.028 & .236 & .098 \\
\hline $\begin{array}{l}\text { Zscore: Extremely and Very Low Income } \\
\text { (\&lt;50\% AMI) }\end{array}$ & .153 & .659 & -.128 & .372 & -.224 \\
\hline Zscore: Renter-occupied & .250 & .618 & -.454 & .355 & -.057 \\
\hline $\begin{array}{l}\text { Zscore: Occupied housing units with no vehicle } \\
\text { available }\end{array}$ & .024 & .596 & .087 & .393 & -.072 \\
\hline Zscore: \&lt; 14 years old & .484 & -.527 & -.305 & -.057 & .342 \\
\hline Zscore: Black or African American Alone & .131 & .459 & .008 & -.027 & .131 \\
\hline Zscore: Asian & -.167 & .294 & -.242 & .132 & -.163 \\
\hline Zscore: $65+$ years old & -.285 & -.161 & .820 & .009 & -.038 \\
\hline Zscore: Receives Social Security Income & -.211 & -.210 & .795 & -.039 & -.044 \\
\hline Zscore: Mobile Homes & -.031 & -.010 & .601 & .019 & -.007 \\
\hline
\end{tabular}




\begin{tabular}{|c|c|c|c|c|c|}
\hline $\begin{array}{l}\text { Zscore: Population between 20-64, all income } \\
\text { levels with a disability }\end{array}$ & .020 & -.194 & .099 & .627 & .011 \\
\hline $\begin{array}{l}\text { Zscore: Households With Supplemental Security } \\
\text { Income (SSI) }\end{array}$ & .080 & -.037 & .105 & .624 & .273 \\
\hline Zscore: Received Food Stamps in Past Year & .555 & .079 & .016 & .575 & .053 \\
\hline $\begin{array}{l}\text { Zscore: Received public assistance income in the } \\
\text { last year }\end{array}$ & .313 & .109 & .048 & .383 & .308 \\
\hline $\begin{array}{l}\text { Zscore: In Civilian Labor Force and Unemployed, } \\
\text { Age } 16^{+}\end{array}$ & .257 & .018 & -.226 & .344 & -.206 \\
\hline Zscore: Lacking Complete Plumbing Facilities & .062 & -.072 & .197 & -.244 & .039 \\
\hline Zscore: Uses public transportation & -.120 & .199 & -.106 & .221 & -.128 \\
\hline Zscore: Two or More Races & -.076 & -.015 & -.127 & .189 & -.010 \\
\hline $\begin{array}{l}\text { Zscore: Native Hawaiian and Other Pacific } \\
\text { Islander alone }\end{array}$ & -.104 & .067 & -.052 & .055 & .730 \\
\hline Zscore: Installation, maintenance, repair & -.048 & -.013 & -.053 & .099 & .643 \\
\hline Zscore: Construction and Extraction & .038 & -.174 & .262 & -.011 & .526 \\
\hline Zscore: \&lt; 5 years old & .282 & -.334 & -.270 & -.012 & .519 \\
\hline $\begin{array}{l}\text { Zscore: Service Occupations: Food, Personal, } \\
\text { Grounds, Maintenance, \&amp;Healthcare }\end{array}$ & .432 & .200 & -.031 & .272 & -.461 \\
\hline
\end{tabular}

Extraction Method: Principal Component Analysis.

Rotation Method: Varimax with Kaiser Normalization.

a. Rotation converged in 7 iterations. 
APPENDIX B: Component Scores and Total Social Vulnerability Score

\begin{tabular}{|c|c|c|c|c|c|c|}
\hline GEO ID & 1 & 2 & 3 & 4 & 5 & Total SVI Score \\
\hline 60790100021 & 0.99218 & 0.39087 & 1.64855 & 0.95076 & 0.21541 & 4.19777 \\
\hline 60790100022 & 0.06717 & 0.54133 & 0.48083 & 1.20429 & 0.462 & 2.75562 \\
\hline 60790100023 & 0.45355 & 0.93902 & 0.76896 & 0.6272 & 1.59277 & 4.3815 \\
\hline 60790100161 & 0.76553 & 0.45157 & 0.0237 & 0.67034 & 1.00964 & 2.92078 \\
\hline 60790100162 & 3.68883 & 0.32328 & 0.71375 & 0.41641 & 0.87697 & 6.01924 \\
\hline 60790101011 & 0.29098 & 0.40593 & 0.33521 & 0.21076 & 0.05775 & 1.30063 \\
\hline 60790101021 & 3.85364 & 0.40187 & 0.10991 & 1.52908 & 0.00679 & 5.90129 \\
\hline 60790101022 & 4.13612 & 0.61766 & 0.97227 & 1.20652 & 0.02285 & 6.95542 \\
\hline 60790101023 & 2.68021 & 0.17196 & 1.28557 & 0.18275 & 0.27411 & 4.5946 \\
\hline 60790101024 & 0.74507 & 1.10322 & 0.41472 & 0.64297 & 1.08569 & 3.99167 \\
\hline 60790101025 & 1.86601 & 0.04424 & 0.23886 & 0.03003 & 1.07176 & 3.2509 \\
\hline 60790102011 & 0.4237 & 0.27799 & 0.43695 & 0.77018 & 0.28469 & 2.19351 \\
\hline 60790102012 & 0.33045 & 0.82961 & 0.6663 & 1.21925 & 0.40339 & 3.449 \\
\hline 60790102021 & 1.1592 & 0.26616 & 0.6632 & 0.15833 & 0.17918 & 2.42607 \\
\hline 60790102022 & 0.85069 & 0.56336 & 0.52595 & 1.17256 & 0.2047 & 3.31726 \\
\hline 60790102041 & 0.8244 & 0.52775 & 0.02631 & 0.87404 & 0.02768 & 2.28018 \\
\hline 60790102042 & 1.42115 & 0.24846 & 0.66667 & 0.34497 & 0.23343 & 2.91468 \\
\hline 60790102051 & 0.20193 & 0.41246 & 0.40755 & 0.23905 & 0.27878 & 1.53977 \\
\hline 60790102052 & 0.86197 & 0.90912 & 0.67808 & 0.33016 & 0.117 & 2.89633 \\
\hline 60790102053 & 0.57215 & 0.84778 & 0.66366 & 0.19017 & 0.16825 & 2.44201 \\
\hline 60790103001 & 0.7839 & 0.30538 & 0.84133 & 0.08418 & 0.35742 & 2.37221 \\
\hline 60790103002 & 0.1698 & 0.5722 & 0.35567 & 0.47823 & 0.39164 & 1.96754 \\
\hline 60790103003 & 1.4106 & 0.50356 & 0.35833 & 0.11668 & 1.6541 & 4.04327 \\
\hline 60790103004 & 0.31171 & 0.86919 & 0.00214 & 1.52433 & 0.32466 & 3.03203 \\
\hline 60790104031 & 0.28436 & 0.4982 & 1.2316 & 0.39895 & 0.92883 & 3.34194 \\
\hline 60790104032 & 0.57079 & 0.16604 & 2.04094 & 0.49366 & 0.86285 & 4.13428 \\
\hline 60790104033 & 0.55106 & 0.00007 & 1.45352 & 0.53917 & 0.44983 & 2.99365 \\
\hline 60790104041 & 0.21791 & 0.2469 & 1.90062 & 0.61086 & 0.7434 & 3.71969 \\
\hline 60790104042 & 1.81208 & 0.41296 & 0.68135 & 0.20271 & 1.23848 & 4.34758 \\
\hline 60790105031 & 0.13795 & 0.24692 & 0.0991 & 0.04092 & 0.00005 & 0.52494 \\
\hline 60790105032 & 0.25416 & 0.55116 & 0.28541 & 0.61634 & 0.0466 & 1.75367 \\
\hline 60790105033 & 0.34075 & 1.04273 & 1.07583 & 0.35831 & 0.34871 & 3.16633 \\
\hline 60790105034 & 0.62029 & 0.17795 & 0.00108 & 3.21172 & 1.02343 & 5.03447 \\
\hline 60790105041 & 0.74256 & 0.73598 & 1.25567 & 0.96997 & 1.54871 & 5.25289 \\
\hline 60790105042 & 0.63304 & 0.23268 & 0.30121 & 0.3951 & 0.62941 & 2.19144 \\
\hline 60790105043 & 0.80394 & 0.07903 & 1.1677 & 0.04849 & 0.92737 & 3.02653 \\
\hline 60790106021 & 1.66907 & 0.16401 & 0.74964 & 0.13226 & 0.46244 & 3.17742 \\
\hline 60790106022 & 0.5231 & 0.01491 & 1.03216 & 0.04064 & 0.77148 & 2.38229 \\
\hline 60790106023 & 0.43121 & 0.00515 & 0.05113 & 0.29647 & 0.39558 & 1.17954 \\
\hline
\end{tabular}




\begin{tabular}{|c|c|c|c|c|c|c|}
\hline 60790106031 & 0.82802 & 0.77938 & 0.52931 & 0.98117 & 1.15069 & 4.26857 \\
\hline 60790106032 & 0.71168 & 0.11857 & 0.30053 & 1.99897 & 0.02792 & 3.15767 \\
\hline 60790107011 & 0.44627 & 0.38922 & 0.00344 & 0.80333 & 0.36014 & 2.0024 \\
\hline 60790107012 & 0.28087 & 0.70404 & 0.3022 & 0.40446 & 0.14683 & 1.8384 \\
\hline 60790107013 & 0.36219 & 0.0326 & 0.60018 & 0.63202 & 0.62152 & 2.24851 \\
\hline 60790107031 & 0.07844 & 0.13975 & 0.68925 & 1.42477 & 0.35317 & 2.68538 \\
\hline 60790107032 & 0.2365 & 0.21618 & 0.12129 & 1.395 & 0.80216 & 2.77113 \\
\hline 60790107071 & 0.63665 & 0.81403 & 0.25023 & 0.2169 & 0.18104 & 2.09885 \\
\hline 60790107072 & 0.62603 & 0.60917 & 0.22898 & 0.23933 & 0.5838 & 2.28731 \\
\hline 60790107073 & 0.80756 & 0.56615 & 0.16021 & 0.01699 & 0.56207 & 2.11298 \\
\hline 60790107074 & 0.61943 & 0.50284 & 0.49497 & 0.54735 & 0.08704 & 2.25163 \\
\hline 60790107075 & 0.17244 & 0.04915 & 1.83954 & 0.68297 & 0.76424 & 3.50834 \\
\hline 60790109011 & 0.55631 & 5.03524 & 1.91055 & 1.70799 & 0.70056 & 9.91065 \\
\hline 60790109012 & 0.87775 & 4.98645 & 1.77908 & 0.88507 & 0.4803 & 9.00865 \\
\hline 60790109021 & 0.03827 & 0.13905 & 1.03439 & 1.72831 & 0.98274 & 3.92276 \\
\hline 60790109022 & 0.56574 & 1.7776 & 1.07932 & 0.03111 & 1.42919 & 4.88296 \\
\hline 60790109023 & 0.37066 & 2.16522 & 1.8097 & 0.01989 & 1.24365 & 5.60912 \\
\hline 60790110011 & 0.23636 & 0.48408 & 0.14338 & 0.55849 & 0.1387 & 1.56101 \\
\hline 60790110012 & 0.88362 & 0.79444 & 0.51842 & 0.89859 & 0.24958 & 3.34465 \\
\hline 60790110013 & 0.53987 & 0.80954 & 0.40688 & 0.07801 & 0.03725 & 1.87155 \\
\hline 60790110021 & 0.11393 & 0.11883 & 0.64624 & 0.67492 & 0.3498 & 1.90372 \\
\hline 60790110022 & 1.1194 & 1.67945 & 2.14068 & 0.30334 & 1.26052 & 6.50339 \\
\hline 60790111011 & 1.03691 & 1.13026 & 1.09324 & 0.75196 & 1.11131 & 5.12368 \\
\hline 60790111012 & 0.32853 & 1.49908 & 0.77502 & 2.28354 & 0.45656 & 5.34273 \\
\hline 60790111013 & 0.7769 & 0.82571 & 1.25349 & 0.1684 & 0.68035 & 3.70485 \\
\hline 60790111021 & 0.55345 & 1.30276 & 0.05122 & 0.81495 & 0.11776 & 2.84014 \\
\hline 60790111022 & 0.23649 & 0.25741 & 1.49047 & 0.16566 & 0.18672 & 2.33675 \\
\hline 60790111023 & 0.78351 & 0.32478 & 0.23558 & 0.5305 & 0.09756 & 1.97193 \\
\hline 60790111024 & 0.00233 & 1.06955 & 0.57483 & 0.29278 & 1.17861 & 3.1181 \\
\hline 60790111031 & 1.1784 & 0.07457 & 0.68048 & 0.40652 & 1.05048 & 3.39045 \\
\hline 60790111032 & 0.48806 & 0.61279 & 1.1811 & 1.70543 & 0.58325 & 4.57063 \\
\hline 60790112001 & 0.63118 & 2.05838 & 1.28431 & 0.15578 & 0.71546 & 4.84511 \\
\hline 60790112002 & 0.88786 & 0.32858 & 0.24199 & 0.62135 & 0.50769 & 2.58747 \\
\hline 60790112003 & 0.92391 & 0.44866 & 0.05431 & 1.24174 & 0.71503 & 3.38365 \\
\hline 60790112004 & 0.666 & 1.56447 & 0.33247 & 0.10312 & 1.02699 & 3.69305 \\
\hline 60790112005 & 0.52279 & 0.03909 & 0.87007 & 1.22187 & 0.11459 & 2.76841 \\
\hline 60790113001 & 0.87966 & 0.18193 & 0.30649 & 0.58508 & 0.57094 & 2.5241 \\
\hline 60790113002 & 0.03242 & 0.09497 & 0.27294 & 0.07809 & 0.62909 & 1.10751 \\
\hline 60790113003 & 0.92699 & 0.14436 & 0.89232 & 0.11191 & 0.32547 & 2.40105 \\
\hline 60790113004 & 0.75602 & 0.31399 & 1.20852 & 0.15269 & 1.03665 & 3.46787 \\
\hline 60790115011 & 0.02258 & 0.30186 & 0.2938 & 0.94641 & 0.58907 & 2.15372 \\
\hline
\end{tabular}




\begin{tabular}{|c|c|c|c|c|c|c|}
\hline 60790115031 & 0.44842 & 0.67136 & 0.97543 & 1.46618 & 0.00099 & 3.56238 \\
\hline 60790115032 & 0.62227 & 0.36677 & 0.78927 & 0.40898 & 0.04479 & 2.23208 \\
\hline 60790115041 & 0.51377 & 0.35569 & 0.74421 & 1.52655 & 0.95369 & 4.09391 \\
\hline 60790115042 & 0.48551 & 2.08894 & 0.94365 & 2.52932 & 0.46233 & 6.50975 \\
\hline 60790116001 & 0.72354 & 0.65228 & 0.28716 & 0.92351 & 0.43755 & 3.02404 \\
\hline 60790116002 & 0.99964 & 0.27804 & 0.64101 & 0.02251 & 1.23219 & 3.17339 \\
\hline 60790116003 & 0.46462 & 0.46774 & 0.177 & 0.29706 & 0.65338 & 2.0598 \\
\hline 60790117011 & 0.54322 & 0.93951 & 6.23435 & 0.8032 & 0.16359 & 8.68387 \\
\hline 60790117012 & 0.68613 & 0.20667 & 0.29546 & 0.81027 & 0.93864 & 2.93717 \\
\hline 60790117013 & 0.23205 & 0.36823 & 0.61813 & 1.57672 & 0.48217 & 3.2773 \\
\hline 60790117014 & 0.25652 & 0.14368 & 0.44646 & 0.85111 & 0.06904 & 1.76681 \\
\hline 60790117041 & 0.92307 & 0.32464 & 0.39473 & 0.21329 & 0.48803 & 2.34376 \\
\hline 60790117042 & 0.58802 & 1.03257 & 0.72116 & 1.48014 & 0.87606 & 4.69795 \\
\hline 60790117043 & 0.96311 & 0.19513 & 0.37878 & 0.22575 & 0.68643 & 2.4492 \\
\hline 60790117044 & 0.77767 & 0.09354 & 1.60098 & 0.89126 & 0.83901 & 4.20246 \\
\hline 60790118001 & 0.21582 & 0.80496 & 1.50248 & 0.78999 & 0.53276 & 3.84601 \\
\hline 60790118002 & 0.96398 & 0.61146 & 0.42052 & 1.30886 & 0.2801 & 3.58492 \\
\hline 60790118003 & 0.96489 & 0.3088 & 0.39612 & 1.16364 & 0.07377 & 2.90722 \\
\hline 60790118004 & 0.39957 & 0.14732 & 0.17518 & 0.16579 & 0.17014 & 1.058 \\
\hline 60790118005 & 0.68431 & 0.72525 & 0.37016 & 0.00248 & 0.46397 & 2.24617 \\
\hline 60790119011 & 0.65832 & 0.26037 & 1.40282 & 0.02431 & 0.13078 & 2.4766 \\
\hline 60790119012 & 0.13604 & 0.07795 & 0.14158 & 0.57961 & 0.06751 & 1.00269 \\
\hline 60790119021 & 0.5448 & 0.08309 & 0.67031 & 0.81697 & 0.37139 & 2.48656 \\
\hline 60790119022 & 0.13251 & 0.13864 & 0.64658 & 0.23006 & 0.24234 & 1.39013 \\
\hline 60790119023 & 0.20571 & 0.01212 & 0.21113 & 0.20807 & 0.07675 & 0.71378 \\
\hline 60790119024 & 1.13198 & 0.64141 & 0.72265 & 1.28465 & 0.01259 & 3.79328 \\
\hline 60790119025 & 0.20459 & 0.83957 & 0.50564 & 0.14261 & 0.2436 & 1.93601 \\
\hline 60790120001 & 0.06063 & 0.46605 & 0.18179 & 1.10022 & 0.36839 & 2.17708 \\
\hline 60790120002 & 1.33597 & 0.76394 & 0.5942 & 0.26144 & 8.91948 & 11.87503 \\
\hline 60790120003 & 0.51197 & 0.03196 & 0.09038 & 2.58873 & 0.47438 & 3.69742 \\
\hline 60790120004 & 0.73141 & 0.57897 & 1.10235 & 0.26175 & 0.28611 & 2.96059 \\
\hline 60790121021 & 0.07517 & 0.29272 & 0.18349 & 1.87274 & 0.90576 & 3.32988 \\
\hline 60790121022 & 0.07606 & 0.3811 & 0.62845 & 0.23695 & 0.09751 & 1.42007 \\
\hline 60790121023 & 0.97914 & 0.22099 & 0.0368 & 3.50613 & 0.35401 & 5.09707 \\
\hline 60790121024 & 0.02583 & 0.03736 & 0.94318 & 2.30448 & 2.60642 & 5.91727 \\
\hline 60790122001 & 3.56339 & 0.55412 & 0.37624 & 0.35155 & 0.71795 & 5.56325 \\
\hline 60790122002 & 0.263 & 0.35137 & 0.65627 & 0.18263 & 1.22396 & 2.67723 \\
\hline 60790122003 & 0.18767 & 0.34442 & 1.51524 & 0.71815 & 0.67587 & 3.44135 \\
\hline 60790122004 & 3.9327 & 0.14258 & 0.42046 & 1.24427 & 0.23562 & 5.97563 \\
\hline 60790123021 & 0.75361 & 0.78995 & 0.16224 & 0.78321 & 0.16656 & 2.65557 \\
\hline 60790123022 & 0.94551 & 0.77256 & 0.13976 & 0.66581 & 0.21465 & 2.73829 \\
\hline
\end{tabular}




\begin{tabular}{|c|c|c|c|c|c|c|}
\hline 60790123023 & 1.03438 & 0.33217 & 0.90072 & 1.62823 & 0.5981 & 4.4936 \\
\hline 60790123041 & 0.16411 & 0.56163 & 0.0455 & 0.44485 & 0.43384 & 1.64993 \\
\hline 60790123042 & 0.31503 & 0.40569 & 0.87655 & 0.31092 & 0.19203 & 2.10022 \\
\hline 60790123043 & 0.15816 & 0.76411 & 0.3241 & 0.00053 & 0.19413 & 1.44103 \\
\hline 60790123044 & 0.23763 & 0.43806 & 0.26283 & 0.26015 & 0.01248 & 1.21115 \\
\hline 60790123045 & 0.83614 & 0.19664 & 2.07339 & 0.80105 & 1.07339 & 4.98061 \\
\hline 60790124011 & 0.55595 & 0.28284 & 0.86042 & 0.32218 & 0.0033 & 2.02469 \\
\hline 60790124012 & 1.8756 & 0.61038 & 0.34891 & 0.33374 & 0.50862 & 3.67725 \\
\hline 60790124013 & 0.69846 & 0.63939 & 0.08625 & 0.46127 & 0.06285 & 1.94822 \\
\hline 60790124021 & 0.40805 & 0.591 & 0.39492 & 1.28338 & 0.14521 & 2.82256 \\
\hline 60790124022 & 0.027 & 0.42782 & 0.86902 & 0.1406 & 0.78631 & 2.25075 \\
\hline 60790124023 & 1.74061 & 0.18859 & 1.31738 & 0.27155 & 0.14918 & 3.66731 \\
\hline 60790125021 & 0.7578 & 0.53613 & 1.00977 & 0.16908 & 0.46078 & 2.93356 \\
\hline 60790125022 & 0.35908 & 0.9741 & 1.15826 & 0.74121 & 0.23985 & 3.4725 \\
\hline 60790125023 & 0.38872 & 0.19708 & 0.7126 & 1.80281 & 0.97276 & 4.07397 \\
\hline 60790125031 & 0.22967 & 0.58346 & 0.32606 & 0.2526 & 0.52903 & 1.92082 \\
\hline 60790125032 & 0.34403 & 0.00579 & 1.03602 & 0.36269 & 0.01357 & 1.7621 \\
\hline 60790125033 & 0.89207 & 0.68814 & 0.74623 & 3.58794 & 1.61608 & 7.53046 \\
\hline 60790125051 & 0.62707 & 0.91695 & 0.28883 & 0.06906 & 0.22879 & 2.1307 \\
\hline 60790125052 & 0.7467 & 0.7143 & 0.21017 & 0.27219 & 0.75868 & 2.70204 \\
\hline 60790125053 & 0.39557 & 0.4967 & 0.93814 & 0.18049 & 0.93192 & 2.94282 \\
\hline 60790126001 & 0.71198 & 0.54326 & 0.29008 & 0.78542 & 0.3125 & 2.64324 \\
\hline 60790126002 & 0.46184 & 0.55739 & 0.92735 & 1.17951 & 0.37554 & 3.50163 \\
\hline 60790126003 & 0.67691 & 0.51941 & 0.82295 & 0.38675 & 0.04144 & 2.44746 \\
\hline 60790126004 & 0.0943 & 0.68019 & 0.77247 & 0.86977 & 0.43472 & 2.85145 \\
\hline 60790126005 & 0.84345 & 0.43832 & 0.254 & 0.88353 & 0.49683 & 2.91613 \\
\hline 60790127021 & 0.68334 & 0.71089 & 0.07359 & 0.1346 & 0.63918 & 2.2416 \\
\hline 60790127022 & 0.2707 & 0.51247 & 0.7439 & 0.07835 & 0.68848 & 2.2939 \\
\hline 60790127023 & 0.62112 & 0.50456 & 0.63603 & 0.00922 & 0.52779 & 2.29872 \\
\hline 60790127024 & 1.08324 & 0.47906 & 0.32619 & 0.71443 & 0.30694 & 2.90986 \\
\hline 60790127025 & 0.27931 & 0.8675 & 0.05628 & 0.46477 & 0.7097 & 2.37756 \\
\hline 60790127041 & 0.19505 & 0.34728 & 1.12275 & 0.65611 & 0.28128 & 2.60247 \\
\hline 60790127042 & 0.73216 & 0.9466 & 0.16826 & 1.00001 & 0.06066 & 2.90769 \\
\hline 60790127043 & 0.21493 & 0.21398 & 0.70389 & 0.28427 & 0.07752 & 1.49459 \\
\hline 60790127044 & 0.50867 & 1.24565 & 1.24068 & 1.51078 & 0.43329 & 4.93907 \\
\hline 60790128001 & 1.86576 & 6.38795 & 3.0368 & 2.0161 & 3.07401 & 16.38062 \\
\hline 60790129001 & 0.39233 & 0.72321 & 0.28589 & 0.35915 & 0.02995 & 1.79053 \\
\hline 60790129002 & 0.221 & 0.75741 & 0.65516 & 0.32021 & 0.20056 & 2.15434 \\
\hline 60790130001 & 0.7304 & 0.37836 & 2.24792 & 1.3052 & 0.96644 & 5.62832 \\
\hline 60790130002 & 0.42978 & 0.10284 & 0.19207 & 1.54286 & 0.24182 & 2.50937 \\
\hline
\end{tabular}




\section{APPENDIX C: Referenced Geospatial Datasets}

The following is a description and sources of the datasets provided for this study, including those for sea-level rise hazards, public infrastructure, buildings, and parcels.

\section{Sea-Level Rise Hazards}

The Pacific Institute report titled "The Impacts of Sea-Level Rise on the California Coast," (Heberger et al., 2009) involved the development of geospatial datasets for hazards induced by sea-level rise, as well as baseline conditions. This study utilizes the following datasets:

- Areas inundated by unimpeded Pacific coastal flooding under baseline (year 2000) conditions

- Areas inundated by unimpeded Pacific coastal flooding under a scenario of 1.4-meter (55-inch) sea-level rise

- Pacific coast bluff erosion hazard zone (high scenario)

- Pacific coast dune erosion hazard zone (high scenario)

- Merged and simplified combined bluff and dune erosion hazard zone

- Coastal wetlands (a filtered subset of wetland polygons from the National Wetlands Inventory that are below or within 100 meters of the MHHW line)

- Mean higher high water elevations at selected long-term Pacific coast tide stations

- Area required for wetland migration under 1.4-meter (55-inch) sea-level rise scenario

- Land cover in area required for wetland migration under 1.4-meter (55-inch) sea-level rise scenario

\section{Public Infrastructure}

In addition, the County Public Works Department provides the following datasets for the purpose of identifying public infrastructure vulnerable to sea-level rise: 
- Boundaries and Spheres of Influence for Cities, Community Service Districts, County Service Areas, and Special Districts

- County maintained roads, bridges, culverts, water systems, sewer lines, stormwater infrastructure, and pipelines

- $\quad$ State pipelines

- All roads, including private roads, trails, and driveways.

\section{Buildings and Parcels}

This study also utilized the following datasets to identify vulnerable buildings, land uses, and other planning designations:

- Building Footprints (retrieved from the County of San Luis Obispo)

- Parcels (retrieved from Cal Poly, San Luis Obispo)

- General Plan Land Use Designations (retrieved from the County of San Luis Obispo)

- Planning Areas (retrieved from the County of San Luis Obispo) 